\title{
Geochemistry and biostratigraphy of Eocene sediments from Samothraki Island, NE Greece
}

\author{
Guido Meinhold, Cambridge, and Marcelle BouDagher-Fadel, London
}

With 6 figures and 3 tables

Meinhold, G. \& BouDagher-Fadel, M. (2010): Geochemistry and biostratigraphy of Eocene sediments from Samothraki Island, NE Greece. - N. Jb. Geol. Paläont. Abh., 256: 17-38; Stuttgart.

\begin{abstract}
Elevated whole-rock concentrations in $\mathrm{Cr}, \mathrm{Ni}$ and $\mathrm{V}$ as well as the occurrence of detrital chrome spinel suggest an input of (ultra)mafic detritus into the Eocene clastic sediments of Samothraki Island. Detrital chrome spinel chemistry indicates a mixed source of MOR-type peridotites and supra-subduction zone (SSZ) peridotites, and minor volcanic rocks, supposedly island-arc basalts and MORB-type rocks, most likely derived from Vardarian ophiolites. Wackestones from the southwest of Samothraki contain a moderately well-preserved calcareous microfossil assemblage, comprising Nummulites fabianii (Prever), Nummulites striatus (Bruguière), Pellatispira sp., and Operculina sp., indicating an early Priabonian age (Late Eocene). The sedimentation of the Eocene succession was influenced by regional tectonic and volcanic activity. The rocks have been deposited contemporaneous with the extensional exhumation of the eastern Rhodope Massif.
\end{abstract}

Keywords: Provenance, chrome spinel, foraminifera, Eocene, Samothraki, Aegean Sea.

\section{Introduction}

Sedimentary provenance analysis of Tertiary deposits in combination with micro-palaeontological studies can provide important hints for palaeotectonic reconstructions of the youngest Tethyan realm, which was marked by subduction, ophiolite obduction and continent-continent collision. Knowledge of the provenance of ancient clastic sedimentary rocks is furthermore important for basin analysis and exploration of natural resources. One of the largest Tertiary basins in the northern Aegean is the Thrace Basin (inset in Fig. 1). In NW Turkey, the Thrace Basin has been intensely studied because it is an important natural hydrocarbon reservoir (e.g. CosKUN 1997, and references therein). Remnants of its southwestern margin are probably represented by Tertiary sedimentary rocks cropping out on Samothraki (Fig.
1) with the oldest known Tertiary deposits there being of Eocene age (Christodoulou 1958; Kopp 1964). They represent an initial transgression phase characterized by shallow marine clastic sedimentation and deposition of nummulitid-bearing limestone. The development of carbonate platforms and clastic deposits at this time was mainly controlled by sealevel fluctuations and large scale extensional tectonics. The latter is recorded, for instance, in ${ }^{40} \mathrm{Ar} /{ }^{39} \mathrm{Ar}$ white-mica cooling ages of ca. 42-35 Ma obtained from metamorphic basement units of the northerly Rhodope Massif (e.g. LIPS et al. 2000; Bonev 2006) and was also discussed for the Serbo-Macedonian Massif to the west (KiLIAs et al. 1999).

Here, we present for the first time data for the provenance of Eocene sediments from Samothraki, and furthermore, we report the discovery of calcareous microfossils, mainly foraminifera, from a new 


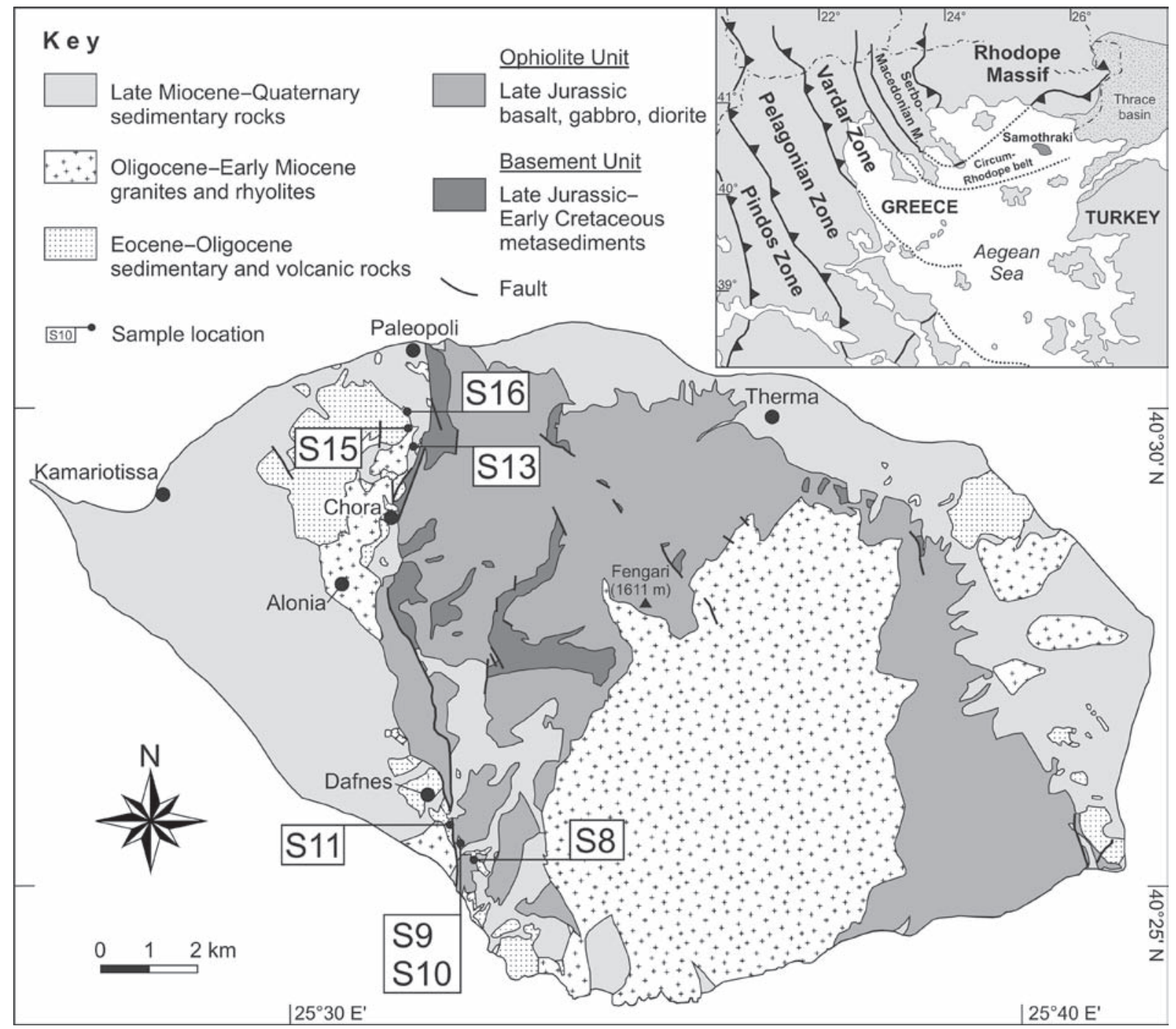

Fig. 1. Simplified geological map of Samothraki (modified from HeImann et al. 1972) with localities of the investigated samples. The inset (upper right) shows the position of Samothraki within the geotectonic zones of Greece (modified from JACOBSHAGEN 1986).

locality in the southwest of the island. The data presented here supplement faunas described by Christodoulou (1958); the only work about foraminifera from Samothraki so far. The Eocene sediments from Samothraki are correlated with formations on the mainland of Greece to the north, and their deposition is discussed within the frame of contemporaneous extensional exhumation of the eastern Rhodope Massif.

\section{Geological setting}

Samothraki is situated in the northeast Aegean Sea, about $40 \mathrm{~km}$ south of the mainland of Greece (Fig. 1), and is generally considered as part of the CircumRhodope Belt (e.g. Tsikouras et al. 1990). The regional geological setting of Samothraki has been described in detail by Davis (1963), HeIMANN (1967) and Tsikouras (1992). The oldest geological unit is the Basement Unit which corresponds to the 'Sedimentäre Serie' of HEIMANN (1967) and the 'slate series' of HEIMANN et al. (1972) respectively, and consists predominantly of clastic up to greenschistfacies metamorphosed sedimentary rocks. Argillaceous slates of greenish-grey to dark grey colour interlayer with quartzose slates and compact quartzites. Medium- to coarse-grained greywacke, grey to light-grey limestone, conglomerates and coarse 


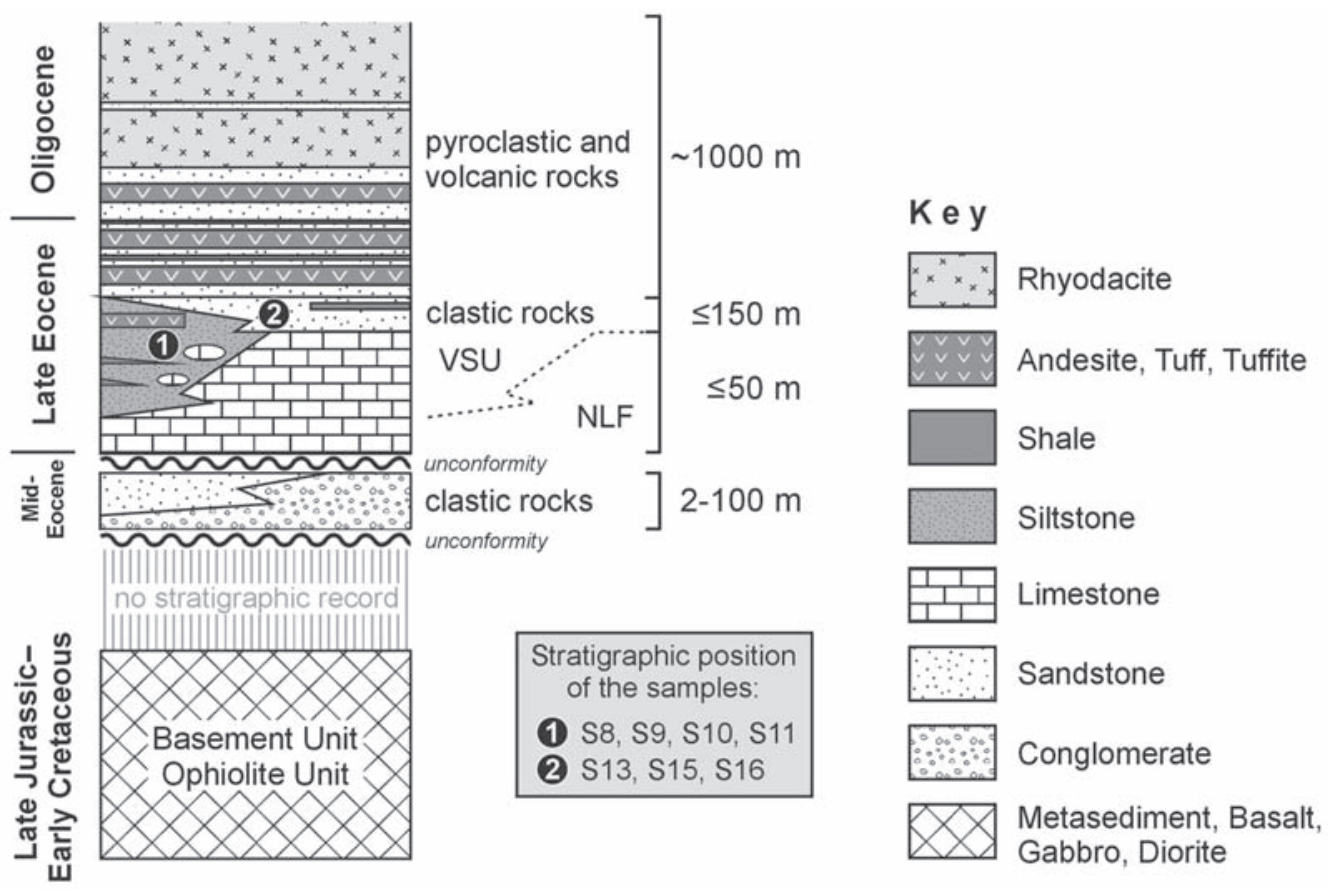

Fig. 2. Schematic stratigraphic column for Samothraki. Compiled after data in Christodoulou (1958), KopP (1964), HeImann (1967), HeimanN et al. (1972) and own field observations. NLF = Nummulitic Limestone Formation, VSU = Volcanosedimentary Unit. The Miocene granitoid in south-central Samothraki (PE-PIPER \& PIPER 2002) and successions younger than Oligocene are not shown in the stratigraphic column.

breccias containing clasts of slate, quartzose slate, greywacke, quartzite and limestone show subordinate occurrence. The metasedimentary rocks are generally suggested to be Late Jurassic to Early Cretaceous in age (for detailed discussion see HEIMANN 1967). They were deposited in a trench, deformed in an accretionary wedge, and later intruded by subduction-related mafic rocks (TsikOURAs et al. 1990) or accumulated in a continental-rift setting (HATZIPANAGIOTOU \& TsiKOURAs 2001). TsiKOuRAs et al. (1990) suggested that the Basement Unit has been partly contact-metamorphosed by the Ophiolite Unit (= Samothraki ophiolite). Later, Tsikouras \& Hatzipanagiotou (1998) suggested an overall tectonic contact between both units. This, however, is not confirmed by our field observation, and therefore, we follow here HeImanN et al. (1972) (see Fig. 1). The Samothraki ophiolite consists mainly of gabbro, basalt, dolerite and diorite (e.g. Tsikouras \& Hatzipanagiotou 1998; Hatzipanagiotou \& Tsikouras 2001). Rare pots of plagiogranite can be also found. The Samothraki ophiolite is generally considered to be subautochthonous, originated in an ensialic back-arc basin, including mid-ocean ridge basalt (MORB) and island-arc tholeiite (IAT) affinities (e.g. TSIKOURAs et al. 1990; TSIKOURAS \& HATZIPANAGIOTOU 1998; Hatzipanagiotou \& Tsikouras 2001). K-Ar hornblende ages of $154 \pm 7$ and $155 \pm 7 \mathrm{Ma}$ for diorite samples were interpreted as intrusion ages (TsIKOURAS et al. 1990). Recently, sensitive high-resolution ion microprobe (SHRIMP II) analyses of zircons from a gabbroic sample gave a mean $\mathrm{U} / \mathrm{Pb}$ age of $159.9 \pm$ 4.5 Ma that was interpreted as the crystallisation age of the gabbro (Koglin 2008; KogLin et al. 2008). The Samothraki ophiolite is seen as eastern continuation of ophiolite complexes from the eastern Vardar Zone (Chalkidiki ophiolite complexes) because of their similarities in geotectonic setting and formation age (Koglin 2008; Koglin et al. 2008). Here, we refer to KoGLIN et al. (2008) who recently presented an evolutionary model for the Samothraki ophiolite complex, including geochemical, isotopic and geochronological data.

Both the Basement Unit and the Ophiolite Unit are locally unconformably overlain by unmetamorphosed Tertiary sedimentary and volcanic rocks (Fig. 2). Most outcrops of Tertiary sediments occur on the western side of the Fengari Mountain; some outcrops are also 
present in the eastern part of the island (Fig. 1). The Tertiary basal succession starts with sandstones and conglomerates of Lutetian age (Middle Eocene) (KopP 1964). The sandstones are fine- to very coarsegrained, greenish-grey in colour and interfinger with poorly sorted conglomerates. The conglomerates are polymict and clast-supported with angular to wellrounded clasts of up to $8 \mathrm{~cm}$ in diameter. The clastic sediments show graded bedding and fining-upward trends - well visible, for example, in outcrops along the main road from Chora to Paleopoli and southeast of Dafnes. Heimann (1967) and Heimann et al. (1972) described mafic clasts from these conglomerates and sandstones. This provides a minimum age for the Samothraki ophiolite (HEIMANN 1967) and a maximum age for ophiolite obduction. The upper part of this clastic succession is built up by fine sandy argillaceous rocks, which contain Globigerina sp., Epistomina sp., Nodosaria sp., and Robulus sp. (Christodoulou 1958) as well as Nummulites, Discocyclina, Pecten and moulds of gastropods (HEIMANN et al. 1972). The basal clastic succession, at some localities also the ophiolite complex itself (e.g. near Chora), are unconformably overlain by nummulitid-bearing limestone (KopP 1964) for which we here use the term Nummulitic Limestone Formation. Main outcrops occur around Chora; other can be found SW of Profitis Ilias, near Lakoma, at Leukopetria, at Cap Kipos and SW of Paleopoli (CHRIsTODOUlou 1958; Davis 1963). The limestone is dark grey to bluish grey. Its thickness varies from 20 m near the cemetery up to $50 \mathrm{~m}$ at the castle ruin of Chora (Kopp 1964). The limestone contains a well-preserved fauna, comprising Asterigerina rotula (KAUfMANN), Eorupertia cristata (GÜMBEL), Schlosserina sp. and Fabiana sp., Heterostegina helvetica (KAUfMANN), Nummulites fabianii (PREVER), Nummulites sp., Gypsina globulus (REUSS), Discocyclina sella (D'ARCHIAC), Discocyclina varians (KaUfFMAnN), Asterocyclina sp., Aktinocyclina sp., Operculina sp., Textularia sp., Pyrgo sp., Triloculina sp. and calcareous algae (Christodoulou 1958) and fragments of
Pecten, echinoderms, corals and coralline algae (Heimann et al. 1972). The Foraminifera assemblage indicates a Priabonian age (Christodoulou 1958). The Nummulitic Limestone Formation is overlain by greenish-grey to yellowish-brown, fine to medium grained sandstones, alternating with sandy calcarenites (HEIMANN et al. 1972). The latter yielded Nummulites cf. fichteli (MichelOTTI), some general fauna of Oligocene age and the algae Lithothamnium sp. (Christodoulou 1958). Towards the upper part, the sandstones are intercalated with conglomerates similar to those from the basal clastic sequence. Furthermore, fine-sandy marls, green and violet to brown tuffaceous shales, sandstones and tuffs are intercalated; in parts also massive andesite occurs (see Kopp 1964; HeIMANN et al. 1972). This upper clastic sequence is well-exposed along the road cut from Chora to Paleopoli. The bedding there dips in mean with $30-55^{\circ}$ to the NW.

Tertiary igneous rocks can mainly be found in the western and eastern part of Samothraki, ranging from basalt to granitoid (e.g. Pe-PIPER \& PiPer 2002, and references therein). Generally in northeastern Greece, the volcanism started with volcaniclastic rocks and ignimbrites in Middle Eocene times, culminated in the Late Oligocene with eruption of calc-alkaline to shoshonitic volcanic rocks and ended in the Miocene with both acidic and intermediate volcanic rocks (e.g. Christofides et al. 2004). In south-central Samothraki, a Miocene granitoid intruded into the ophiolite complex (PE-PIPER \& PIPER 2002). The intensive Tertiary volcanism in the northeastern Aegean region was related either to the subduction of the IntraPontide Ocean (e.g. Pe-PIPER \& PIPER 2006), which is suggested to have been closed in the Oligocene (GÖRÜR \& OKAY 1996), or it was associated with crustal extension after the thickening/uplift of the Hellenic orogen as the result of under-thrusting of the African plate beneath the southern European margin (e.g. Christofides et al. 2004). The youngest successions on Samothraki are marine sediments of Pliocene age (DAVIs 1963) and Quaternary deposits.

Table 1. Sample list.

\begin{tabular}{|c|c|c|c|c|}
\hline Sample & Rock type & Locality & Latitude & Longitude \\
\hline $\begin{array}{l}\text { S8 } \\
\text { S9 } \\
\text { S10 } \\
\text { S11 } \\
\text { S13 } \\
\text { S15 } \\
\text { S16 }\end{array}$ & $\begin{array}{l}\text { siltstone } \\
\text { wackestone } \\
\text { wackestone } \\
\text { siltstone } \\
\text { sandstone } \\
\text { sandstone } \\
\text { sandstone }\end{array}$ & $\begin{array}{l}\text { SE' Dafnes } \\
\text { SE' Dafnes } \\
\text { SE' Dafnes } \\
\text { SE' Dafnes } \\
\text { N' Chora } \\
\text { N' Chora } \\
\text { N' Chora }\end{array}$ & $\begin{array}{l}\text { N } 40^{\circ} 24^{\prime} 52.5^{\prime \prime} \\
\text { N } 40^{\circ} 25 ' 03.4^{\prime \prime} \\
\text { N } 40^{\circ} 25^{\prime} 03.4^{\prime \prime} \\
\text { N } 40^{\circ} 25^{\prime} 19.5^{\prime \prime} \\
\text { N } 40^{\circ} 28^{\prime} 52.3^{\prime \prime} \\
\text { N } 40^{\circ} 29^{\prime} 12.3^{\prime \prime} \\
\text { N } 40^{\circ} 29^{\prime} 24.6^{\prime \prime}\end{array}$ & 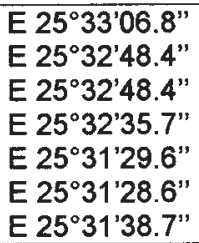 \\
\hline
\end{tabular}


Table 2. Whole-rock chemical data of Lower Tertiary sedimentary rocks from Samothraki. Total iron is expressed as $\mathrm{Fe}_{2} \mathrm{O}_{3}$.

\begin{tabular}{|c|c|c|c|c|c|}
\hline Sample & S8 & S11 & $\mathbf{S 1 3}$ & $\mathbf{S 1 5}$ & S16 \\
\hline Lithology & siltstone & siltstone & sandstone & sandstone & sandstone \\
\hline $\mathrm{SiO}_{2}(\mathrm{wt} \%)$ & 55.54 & 51.45 & 60.50 & 65.36 & 58.39 \\
\hline $\mathrm{TiO}_{2}$ & 0.94 & 0.97 & 1.11 & 0.81 & 1.04 \\
\hline $\mathrm{Al}_{2} \mathrm{O}_{3}$ & 16.95 & 15.35 & 13.96 & 12.40 & 12.80 \\
\hline $\mathrm{Fe}_{2} \mathrm{O}_{3}$ & 6.89 & 7.88 & 8.15 & 5.72 & 8.00 \\
\hline MnO & 0.03 & 0.10 & 0.04 & 0.04 & 0.10 \\
\hline $\mathrm{MgO}$ & 2.48 & 4.11 & 1.18 & 0.98 & 2.17 \\
\hline $\mathrm{CaO}$ & 2.99 & 6.43 & 3.79 & 3.54 & 5.82 \\
\hline $\mathrm{Na}_{2} \mathrm{O}$ & 1.41 & 2.06 & 2.02 & 2.75 & 2.14 \\
\hline $\mathrm{K}_{2} \mathrm{O}$ & 2.98 & 2.15 & 1.19 & 0.65 & 0.93 \\
\hline $\mathrm{P}_{2} \mathrm{O}_{5}$ & 0.15 & 0.13 & 0.10 & 0.09 & 0.10 \\
\hline LOI & 8.33 & 8.81 & 7.06 & 6.35 & 8.06 \\
\hline Total & 98.71 & 99.44 & 99.10 & 98.69 & 99.54 \\
\hline Sc (ppm) & 23 & 23 & 39 & 12 & 32 \\
\hline v & 162 & 146 & 238 & 151 & 196 \\
\hline $\mathrm{Cr}$ & 160 & 126 & 334 & 199 & 260 \\
\hline Co & 7 & 22 & 30 & 15 & 34 \\
\hline $\mathrm{Ni}$ & 78 & 53 & 140 & 53 & 91 \\
\hline $\mathrm{Cu}$ & 26 & 26 & 38 & 12 & 29 \\
\hline $\mathrm{Zn}$ & 111 & 113 & 89 & 62 & 82 \\
\hline $\mathrm{Ga}$ & 23 & 19 & 18 & 14 & 15 \\
\hline $\mathrm{Rb}$ & 141 & 97 & 49 & 24 & 38 \\
\hline $\mathrm{Sr}$ & 140 & 196 & 92 & 88 & 122 \\
\hline$Y$ & 33 & 31 & 28 & 17 & 29 \\
\hline $\mathrm{Zr}$ & 183 & 195 & 169 & 116 & 145 \\
\hline $\mathrm{Nb}$ & 17 & 14 & 10 & 8 & 8 \\
\hline $\mathrm{Ba}$ & 619 & 382 & 215 & 132 & 212 \\
\hline Th & 14 & 11 & 4 & 3 & 3 \\
\hline $\mathbf{U}$ & 4 & 2 & 4 & 0 & 1 \\
\hline La & 51 & 29 & 20 & 14 & 14 \\
\hline $\mathrm{Ce}$ & 67 & 55 & 39 & 27 & 31 \\
\hline Pr & 11 & 7 & 3 & 7 & 9 \\
\hline $\mathrm{Nd}$ & 41 & 30 & 20 & 17 & 20 \\
\hline $\mathrm{Sm}$ & 7 & 5 & 5 & 5 & 3 \\
\hline
\end{tabular}

\section{Provenance}

A total of seven samples including two wackestones, two siltstones and three sandstones were collected from the Eocene sedimentary succession of Samothraki (Fig. 1) for whole-rock major- and trace-element geochemical analyses, detrital mineral chemistry and biostratigraphy. Sample localities (including geographic coordinates) and the analytical whole-rock geochemical and selected mineral chemical data are given in Tables 1, 2 and 3 respectively. The remaining analytical data are given in the Appendix.

The Eocene sandstones are poorly sorted by size and dominated by angular to sub-angular clasts. They consist of mono- and poly-crystalline quartz and sedimentary and volcanic lithoclasts. The latter are mainly mafic in composition. Serpentinized ultramafic rock fragments have also been found. Feldspar grains are 
Table 3. Representative EMP data of detrital chrome spinel and inclusions. Total iron measured is expressed as FeO.

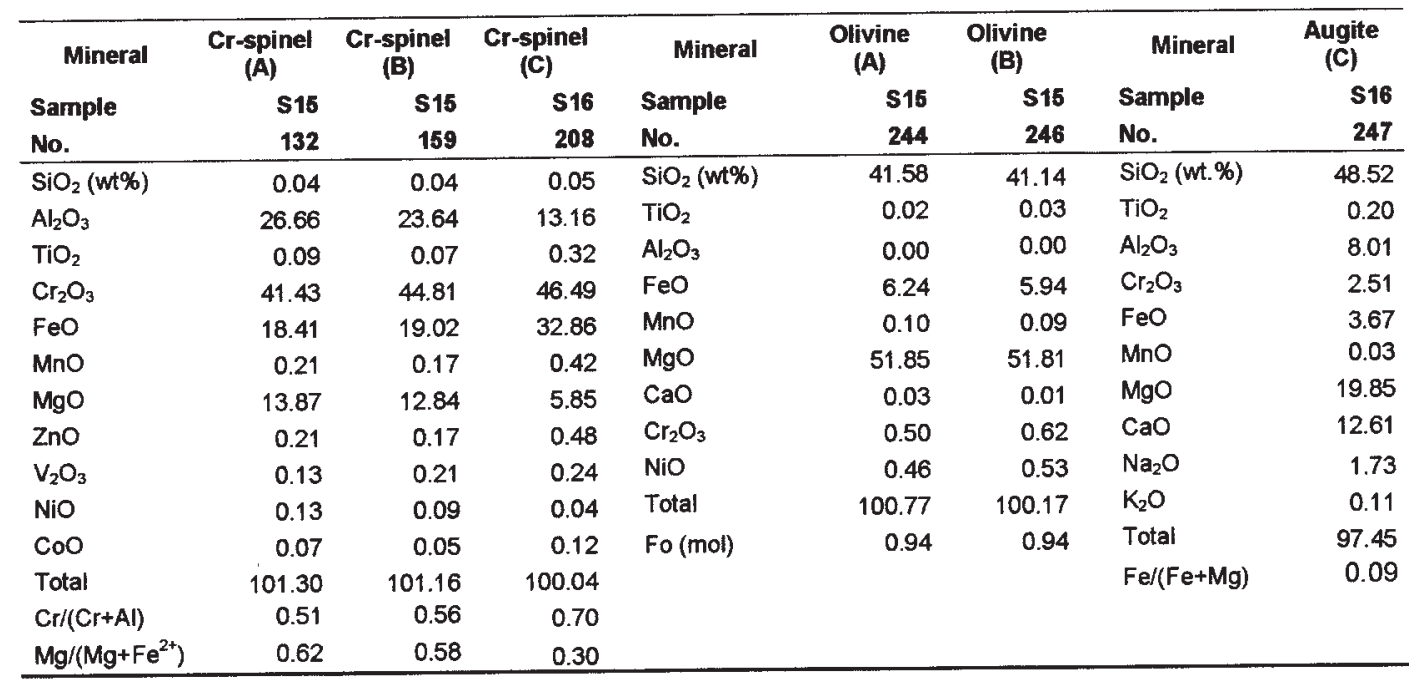

common and always present. Plagioclase (mainly albite) is by far the most abundant feldspar, whereas $\mathrm{K}$-feldspar is very rare (see below). Plagioclase grains often display patchy alteration due to sericitisation. Single muscovite flakes are rare. Accessory minerals include epidote, opaque minerals, chrome spinel and zircon.

\section{Whole-rock geochemical data}

Whole-rock major- and trace-element concentrations of selected samples were determined by X-ray fluorescence (XRF) at the University of Mainz (see MEINHOLD et al. 2007 for analytical details). The siltstones and sandstones are characterised by low contents of $\mathrm{SiO}_{2}(51-65 \mathrm{wt} \%)$ and $\mathrm{MnO}(0.03-0.1 \mathrm{wt} \%)$, and medium to high contents of $\mathrm{TiO}_{2}(0.81-1.11 \mathrm{wt} \%)$, $\mathrm{Fe}_{2} \mathrm{O}_{3}(5.72-8.15 \mathrm{wt} \%)$ and $\mathrm{Na}_{2} \mathrm{O}(1.41-2.75 \mathrm{wt} \%)$. $\mathrm{Na}_{2} \mathrm{O}$ correlates positively with $\mathrm{SiO}_{2}$ and $\mathrm{Al}_{2} \mathrm{O}_{3}$ indicating that $\mathrm{Na}$ is fixed in Na-feldspar. The strong positive linear correlations between $\mathrm{K}_{2} \mathrm{O}$ and $\mathrm{Rb}$ with $\mathrm{Al}_{2} \mathrm{O}_{3}$ suggest that both $\mathrm{K}$ and $\mathrm{Rb}$ reside in phyllosilicates. The high content of the latter together with the distinct amount of mafic clasts and organic matter probably causes the high loss on ignition (LOI) of around 6 to $9 \mathrm{wt} \%$. Compared to upper continental crustal values $(\mathrm{Cr} \sim 92, \mathrm{Ni} \sim 47, \mathrm{~V} \sim 97$ : RUDNICK \& GAO 2003), all samples are characterised by elevated contents of $\mathrm{Cr}$ (126-334 ppm), Ni (53-140 ppm) and V (146-238 ppm) (Fig. 3), which suggest an input of an (ultra)mafic component. According to GARVER et al. (1994), $\mathrm{Cr} / \mathrm{Ni}$ ratios of 2.1-3.8 of the studied samples indicate an input of mafic volcanic detritus into the Eocene clastic succession, thereby the $\mathrm{Cr} / \mathrm{Ni}$ ratio of 3.8 (sample S15) suggests significant sedimentary fractionation. Input of an (ultra)mafic component is confirmed by occurrence of detrital chrome spinel in the sandstone samples (see below). However, especially for the fine-grained sediments, which are intercalated with tuffs and andesites, the contemporaneous intermediate (andesitic) volcanism has to be kept in mind as a possible $\mathrm{Cr}$, $\mathrm{Ni}$ and $\mathrm{V}$ supplier. According to BHATIA \& CROOK (1986) using the relatively immobile trace elements $\mathrm{La}, \mathrm{Th}, \mathrm{Zr}$, and $\mathrm{Sc}$, the tectonic setting of the sandstone samples S13 and S16 (Fig. 1 for sample location) can be given to be of an ocean island arc, whereas sample S15 tends to be of a continental island arc.

\section{Mineral chemical data}

Beside petrography and whole-rock geochemistry microprobe analysis of detrital mineral phases has great potential to determine the petrology of source rocks (e.g. VON EYNATTEN \& GAUPP 1999). Therefore, the chemistry of detrital feldspar grains were randomly analysed in polished thin sections and detrital chrome spinel, including few inclusions, in mineral separates. Sample preparation for mineral separates followed those described in MeINHOLD et al. (2007). Electron-microprobe analyses were performed with a JEOL JXA 8900 RL instrument at the University of 


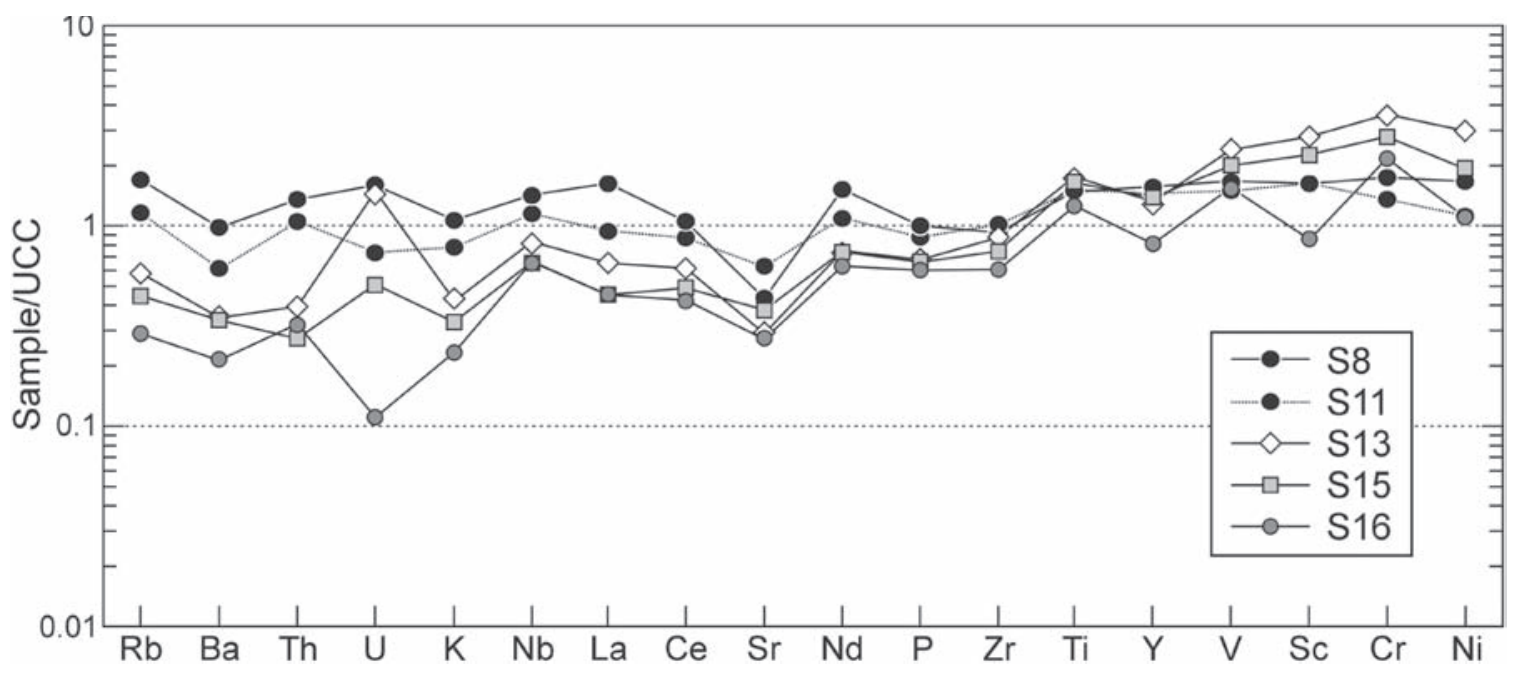

Fig. 3. Multi-element diagram for Eocene clastic sediments from Samothraki. Concentrations are normalised against the upper continental crust composition (UCC, RUDNICK \& GAO 2003).

Mainz, equipped with 5 wavelength-dispersive spectrometers. Microprobe conditions for chrome spinel and inclusions of clinopyroxene and olivine were $20 \mathrm{kV}$ acceleration voltages, with a beam current of $12 \mathrm{nA}$, and a beam diameter of $2 \mu \mathrm{m}$. Feldspar was analysed with $15 \mathrm{kV}$ acceleration voltages, a beam current of $8 \mathrm{nA}$, and a beam diameter of $5 \mu \mathrm{m}$. Natural and synthetic materials have been used as standards. Mineral composition of inclusions and their host chrome spinels are shown in Table 3. Cations were calculated assuming stoichiometry. The remaining analytical data used in this paper are given in the Appendix.

The analysed detrital feldspar grains (in total 93) are characterised by $\mathrm{Ab}_{85-100} \mathrm{An}_{0-4} \mathrm{Or}_{0-13}$ in sample $\mathrm{S} 13$ and $\mathrm{Ab}_{85-99} \mathrm{An}_{0-12} \mathrm{Or}_{0-14}$ in sample $\mathrm{S} 16$. The feldspars have high $\mathrm{Na}_{2} \mathrm{O}$ contents but low contents of $\mathrm{CaO}$ and $\mathrm{K}_{2} \mathrm{O}$, which indicates albite composition. Only two grains are anorthoclase and two grains oligoclase in composition. A prominent content of detrital albite reflects sediment supply from volcanic rocks (TREVENA \& NASH 1981) and/or low-grade metamorphic rocks of the chlorite and biotite zones (DEER et al. 1992). Nonetheless, we want to emphasize here that the application of detrital feldspar and its chemical composition for provenance analysis is of limited value due to its instability during weathering and during metamorphic overprint.

Detrital chrome spinel was found in Eocene clastic sediments from Samothraki, which confirms an input of (ultra)mafic rocks from the source area as suggested by whole-rock geochemistry. In general, detrital chrome spinel is known as provenance indicator of mafic and ultramafic rocks, and its chemistry reflects the geotectonic setting of source rocks from which it was derived (e.g. Dick \& Bullen 1984; Pober \& Faupl 1988; CoOKenboo et al. 1997; BARnes \& Roeder 2001; KAMENETSKy et al. 2001). Following common practice for chrome spinel interpretation, the $\mathrm{Cr}$-number $[\mathrm{Cr} /(\mathrm{Cr}+\mathrm{Al})]$ and $\mathrm{Mg}$ number $\left[\mathrm{Mg} /\left(\mathrm{Mg}+\mathrm{Fe}^{2+}\right)\right]$ for each analysis were calculated assuming stoichiometry. The major-element composition of the analysed grains (in total 198) shows a broad range that suggests multiple source areas for the chrome spinels. Minor variation may also be through alteration or weathering processes. Traceelement concentrations are consistently low, with $\mathrm{NiO}$ $<0.25 \mathrm{wt} \%, \mathrm{~V}_{2} \mathrm{O}_{3}<0.41 \mathrm{wt} \%, \mathrm{ZnO}<0.84 \mathrm{wt} \%$ and $\mathrm{CoO}<0.17 \mathrm{wt} \%$. Using the diagram of POBER \& FAuPL (1988), the observed spread in Cr-number (0.28-0.82) and Mg-number (0.12-0.77) suggests a mixed (ultra)mafic source of highly depleted peridotites of mainly harzburgite and minor lherzolite composition (Fig. 4a). A distinct amount of chrome spinel plots in the field for metamorphic spinel (Fig. 4a). These chrome spinels have also very low $\mathrm{Fe}^{3+}$ / $\mathrm{Cr}+\mathrm{Al}+\mathrm{Fe}^{3+}$ ) ratios that specifies their metamorphic origin as being derived from high-grade metamorphic rocks (BARNeS \& RoEder 2001). Following KAMENETSKY et al. (2001), the analysed chrome spinels can 

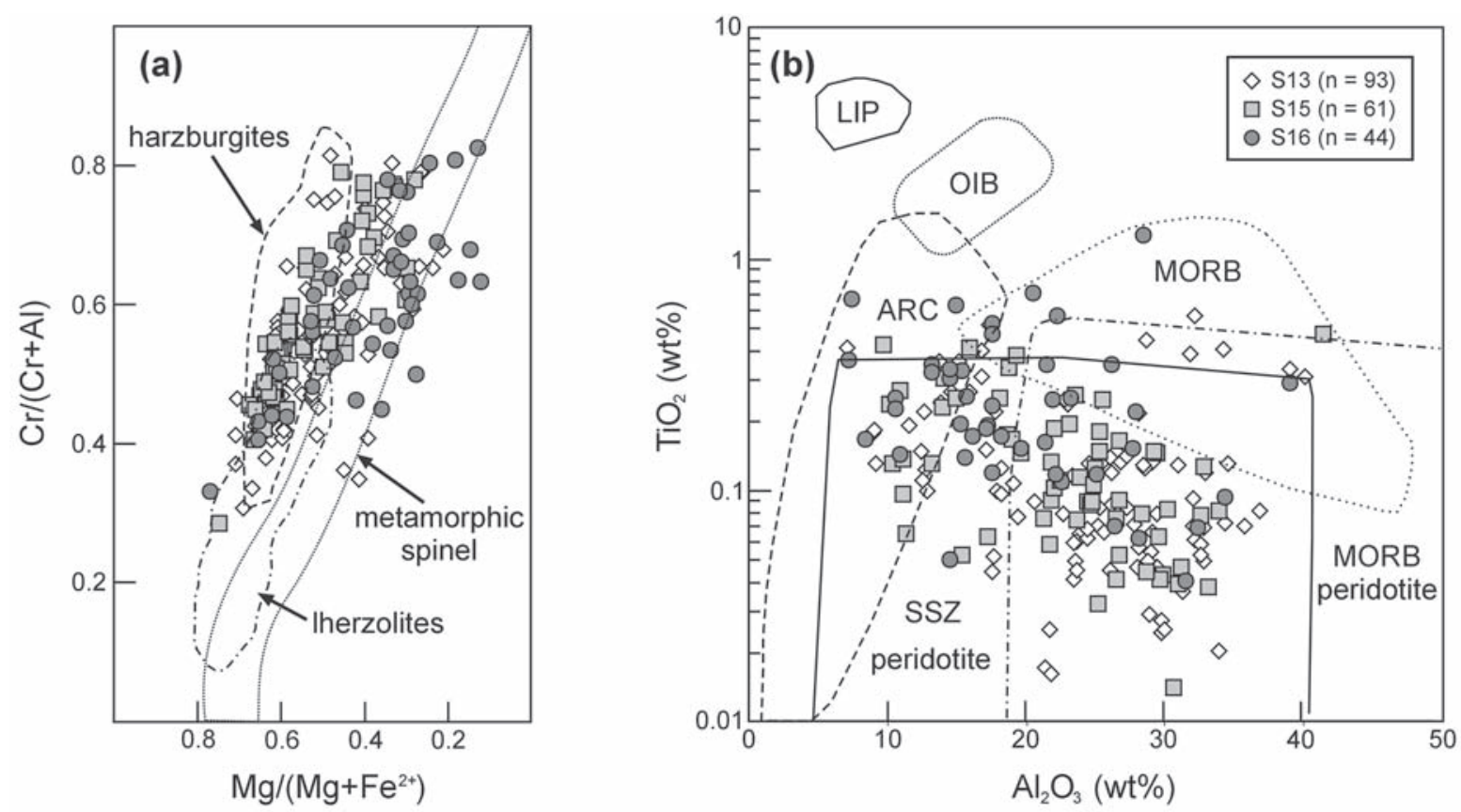

Fig. 4. Compositional data of detrital chrome spinel from Eocene clastic sediments of Samothraki. (a) $\mathrm{Cr} /(\mathrm{Cr}+\mathrm{Al})$ vs. $\mathrm{Mg} /\left(\mathrm{Mg}+\mathrm{Fe}^{2+}\right)$ diagram showing the discrimination of chrome spinel derived from the two major peridotite subtypes after PoBER \& FAUPL (1988). (b) $\mathrm{TiO}_{2}$ vs. $\mathrm{Al}_{2} \mathrm{O}_{3}$ diagram showing the discrimination fields of chrome spinel derived from various types of mafic and ultramafic rocks after KAMENETSKY et al. (2001). MORB = mid-ocean ridge basalt, $\mathbf{O I B}=$ ocean-island basalt, $\mathbf{L I P}=$ large igneous province, $\mathbf{A R C}=$ island-arc magmas, $\mathbf{S S Z}=$ supra-subduction zone.

be separated into spinels derived from peridotitic and volcanic source rocks on the basis of their $\mathrm{TiO}_{2}$ contents and $\mathrm{Fe}^{2+} / \mathrm{Fe}^{3+}$ ratios. Around $72 \%$ of all chrome spinels have $\mathrm{TiO}_{2}$ concentrations less than $0.2 \mathrm{wt} \%$ and $\mathrm{Fe}^{2+} / \mathrm{Fe}^{3+}$ ratios higher than 2.39 that suggest peridotites as source rocks. Combined with the $\mathrm{Al}_{2} \mathrm{O}_{3}$ vs. $\mathrm{TiO}_{2}$ diagram of KAMENETZKY et al. (2001), most of the detrital chrome spinels were derived from MOR-type peridotites and supra-subduction zone (SSZ) peridotites, whereas only a small fraction comes from volcanic rocks, supposedly island-arc basalts and MORB-type rocks (Fig. 4b).

One clinopyroxene inclusion was found in a chrome spinel grain of sample S16. Its chemical composition and those of the host chrome spinel is shown in Table 3. The clinopyroxene has a relatively high content of $\mathrm{Al}_{2} \mathrm{O}_{3}(8.01 \mathrm{wt} \%)$ and $\mathrm{Cr}(2.51 \mathrm{wt} \%)$ with $\mathrm{En}_{59.8}, \mathrm{Wo}_{27.3}, \mathrm{Fs}_{6.2}$ and $\mathrm{Ac}_{6.8}$. The clinopyroxene inclusion can be classified as Cr-rich augite, according to Morimoto (1988).

Beside augite also two inclusions of olivine were found. Their chemical composition and those of the host chrome spinels is shown in Table 3. Both in- clusions are Fo-rich olivine $\left(\mathrm{Fo}_{94}\right), \mathrm{NiO}$ is around $0.5 \mathrm{wt} \%$, and the contents of $\mathrm{TiO}_{2}$ and $\mathrm{CaO}$ are very low $(<0.05 \mathrm{wt} \%)$. The presence of olivine inclusions in chrome spinel allows application of the olivinespinel geothermometer, which base on the exchange of $\mathrm{Fe}$ and $\mathrm{Mg}$ between coexisting olivine and spinel, and gives the closure temperature for the $\mathrm{Fe}-\mathrm{Mg}$ exchange between both phases (KAMENETZKY et al. 2001). The equilibration temperatures calculated at an arbitrary pressure of $10 \mathrm{kbar}$ using the olivine-spinel geothermometer of BALLHAUs et al. (1991) are $945^{\circ} \mathrm{C}$ for olivine-spinel pair A and $925^{\circ} \mathrm{C}$ for olivine-spinel pair B. These temperatures are close to minimum equilibration temperatures of $\sim 950{ }^{\circ} \mathrm{C}$ for clinopyroxenes of gabbros from the Samothraki ophiolite (Tsikouras \& Hatzipanagiotou 1998).

\section{Micropalaeontological data}

The fossiliferous samples S9 and S10 were collected ca. $600 \mathrm{~m}$ southeast of Dafnes village along the main road to Pachia Ammos (Fig. 1). The sedimentary succession here is intercalated with intermediate 

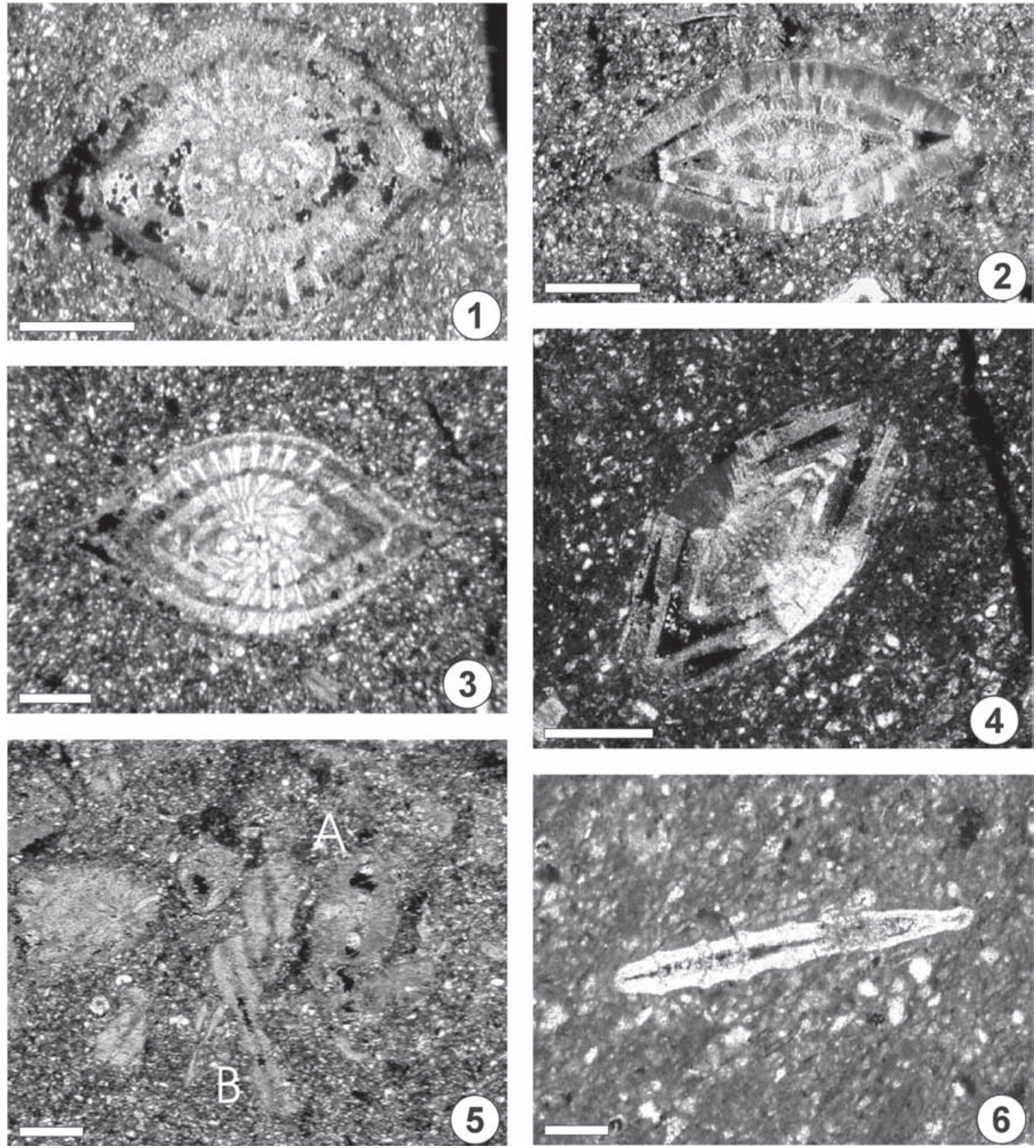

Fig. 5. Transmitted light microphotographs of Late Eocene Foraminifera from Samothraki identified in thin sections. Scale bar represents $0.5 \mathrm{~mm}$ in all images. The thin sections with the illustrated specimens are deposited in the Senckenberg Museum in Frankfurt am Main (SMF), Germany (SMF collection numbers). 1. Nummulites fabianii (PreVER), SMF XXVII 5791, sample S9. 2. Nummulites fabianii (Prever), SMF XXVII 5791, sample S9. 3. Nummulites fabianii (Prever), SMF XXVII 5790, sample S9. 4. Nummulites striatus (BruguiÈre), SMF XXVII 5790, sample S9. 5. A. Pellatispira sp., B. Operculina sp., SMF XXVII 5791, sample S9. 6. Operculina sp., SMF XXVII 5792, sample S 10.

(andesitic) volcanic rocks (tuff, tuffite, andesite). In the ensuing paragraphs we use the lithostratigraphic term Volcanosedimentary Unit. The sediment is mas- sive and of dark greenish-grey colour. The framework grains are mainly monocrystalline quartz with an angular shape and muscovite flakes. Minor opaque 
minerals and sporadic calcite clasts occur. According to the classification scheme of DunHAM (1962), sample S9 can be classified as fossiliferous micritic wackestone. This rock type has abundant microfossils, such as benthic foraminifera. Macrofossils, such as gastropods and bivalves, were found in similar rocks in the vicinity. Wackestones of the Volcanosedimentary Unit have mostly a brownish crust of iron oxides and hydroxides on strongly weathered surfaces. Dark grey limestone lenses (fossiliferous wackestones, e.g. sample S10) up to $25 \mathrm{~cm}$ in length occur sporadically within a fine-grained clastic succession, consisting mainly of siltstones and fine-grained sandstones.

\section{Foraminiferal data}

The collected samples are made of fossiliferous wackestone of larger benthic foraminifera. Sample S9 contains a nummulitic assemblage of Nummulites striatus (BRUguiÈre), Nummulites fabianii (PreVER), Pellatispira sp., and Operculina sp. whereas sample S10 only contains Nummulites striatus (BRUGUIĖE) and Operculina sp. Photographs of the age diagnostic taxa and their stratigraphic range are given in Figures 5 and 6 respectively. According to SCHAUB (1981), the biostratigraphic range of $N$. striatus (BRUGUIÈRE) comprises the late Bartonian and the early Priabonian. Nummulites fabianii (Prever) is restricted to the Priabonian; its first occurrence defines the BartonianPriabonian boundary (e.g. SERRA-KIEL et al. 1998). Pellatispira ranges from the late Bartonian to the Priabonian (see BOUDAGHER-FADEL 2008), and the longranging genus Operculina occurs from the Paleocene to Recent. The occurrence of Nummulites striatus (Bruguière) with N. fabianii (PREVER) indicates an early Priabonian age (Late Eocene). According to the Shallow Benthic Zones (SBZ) defined by SERRA-KIEL et al. (1998), the nummulitic assemblage of sample S9 can be assigned to SBZ 19 whereas sample S10 ranges from SBZ 17 to SBZ 19.

\section{Palaeoenvironment}

The larger benthic foraminifera are represented mainly by thin and flat forms suggesting moderate to deep water deposition within the photic zone, such as Operculina sp. and Nummulites spp. Of the nummulitids Operculina is the most "primitive" genus known and the least specialised (COLE 1957). For this reason it is thought to be less dependant on coralline algae symbionts for food and therefore inferred to have a wider environmental range than the other nummulitids (COLE 1957). The Recent nummulitid Operculina appears to be restricted to oceanic salinities and has been found at depths as shallow as $14 \mathrm{~m}$ and lives on soft-bottomed substrates in the Gulf of Aqaba at depths of 30-150 m, with flatter forms most common between 60-120 m (HotTINGER 1983). It dominates low-energy, muddy seabeds, and in the Oligocene-Miocene this genus is inferred to inhabit environments ranging from high-energy, shallow water fore-reef facies (BOUDAGHER-FADEL et al. 2000) down to quiet waters near the base of the photic zone (CHAPRONIERE 1975). The thin flat shapes of this nummulitic assemblage are thought to be an adaptation to light attenuation with increasing habitat depth (Hallock \& Schlager 1986). This, together with the micrite matrix common in this facies, suggests a rather low-energy depositional setting towards the base of the photic zone (BOUDAGHER-FADEL 2002), probably in the outer ramp.

\section{Discussion}

Whole-rock geochemical data of Eocene clastic sediments from Samothraki indicate a significant input of (ultra)mafic detritus from the source area. That is confirmed by the presence of detrital chrome spinel in the heavy mineral spectrum. The mineral chemistry of detrital chrome spinel grains shows dominantly a harzburgitic composition and suggests a mixed source of MOR-type peridotites and supra-subduction zone (SSZ) peridotites, whereas only a small fraction comes from volcanic rocks, supposedly island-arc basalts and MORB-type rocks. We suggest that the Eocene clastic sediments of Samothraki received their (ultra)mafic detritus from Vardarian ophiolites with similarities to the Chalkidiki, Evros and Samothraki ophiolite complexes since these complexes comprise various types of mafic and/or ultramafic rocks of mid-ocean ridge, island-arc and supra-subduction zone affinities (TsIKOURAS et al. 1990; TsIKOURAS 1992; Tsikouras \& Hatzipanagiotou 1998; MAGGANAS 2002; Pe-PIPER \& PiPER 2002; ZaChARIADIS 2007; Bonev \& Stampfli 2008a, b; Koglin 2008; KoGLIN et al. 2008). Another source might have been metamorphosed mafic-ultramafic rocks (amphibolite, eclogite, metagabbro, peridotite, and dunite) from the high-grade metamorphic complex of the Rhodope Massif (e.g. Liati \& Gebauer 1999; Liati 2005; BONEv 2006; Bonev et al. 2006), which could explain 


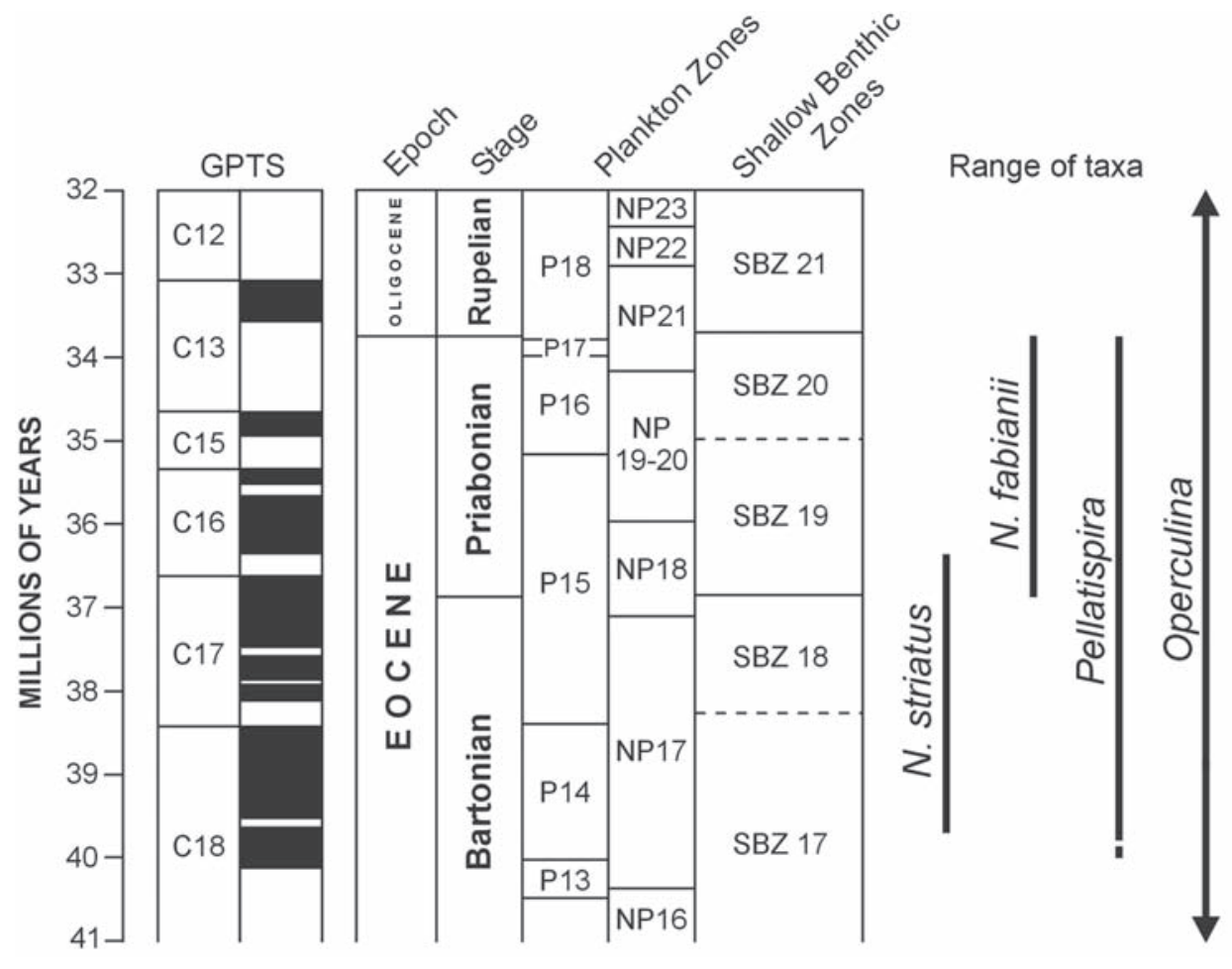

Fig. 6. Chronostratigraphic range of Foraminifera from Samothraki identified in thin sections. The global paleomagnetic time scale (GPTS) and the biozonations are according to SERRA-KIEL et al. (1998). $\mathbf{N}=$ Nummulites.

the distinct amount of metamorphic spinel found in the Eocene clastic sediments of Samothraki. This however remains speculative and needs further verification.

The new biostratigraphic data presented here confirm the presence of fossiliferous Priabonian (Upper Eocene) sedimentary rocks on Samothraki. The Foraminifera assemblages of the wackestone samples from the Volcanosedimentary Unit suggest a low-energy depositional setting towards the base of the photic zone. Moreover, the data show clearly for Samothraki that the intermediate (andesitic) volcanism started already during the early Priabonian. It was however not restricted to Samothraki alone. Intermediate volcanic rocks of Priabonian age have also been described by KopP (1965) from the mainland of northeastern Greece (see also SKAPELIS et al. 1987). It seems that in northeastern Greece the volcanic activity is older than Oligocene; it started possibly in Mid-Eocene times (e.g. Christofides et al. 2004). This intermediate volcanism was probably linked to the geotectonic reorganisation in the northeastern Aegean region at that time. According to CHRIsto-
FIDES et al. (2001), it could be related to the transition from a pre-plate collision geotectonic setting in the early Eocene to a mostly post-collision geotectonic setting in the Oligocene-Miocene. According to the tectonic model of Bonev (2006), the Priabonian intermediate volcanism more likely coincides with the transition from syn- to post-orogenic extension in the Eastern Rhodope. An in-depth analysis of this topic, however, is beyond the scope of the present paper.

The occurrence of Nummulites fabianii (PREVER) in the Nummulitic Limestone Formation of Samothraki clearly shows its Priabonian age (Late Eocene) (Christodoulou 1958). Thus, at least a part of the shallow water taxa therein has to be interpreted as reworked. Furthermore, it clearly shows that the Nummulitic Limestone Formation on Samothraki is slightly younger than the Nummulitic Limestone Formation ("Nummulitenkalk" of KopP 1965) on the mainland of Greece, for that a Lutetian-Bartonian age (Middle Eocene) is suggested on the basis of foraminifera assemblages (KopP 1965). Based on lithology and biostratigraphic age, the Nummulitic Limestone Formation and the Volcanosedimentary Unit on 
Samothraki can be seen as time and facies equivalent units to the Upper Eocene succession described by Kopp (1965) from the mainland of Greece.

The Nummulitic Limestone Formation probably represents a shallow margin carbonate ramp deposited on structural highs in front of the uppermost parts of a progressive "orogenic wedge". The latter was most likely represented by units of the collapsing Rhodope Massif to the North, which at that time was characterised by extensional exhumation and doming (e.g. Lips et al. 2000; Bonev 2006; Bonev et al. 2006). Abrupt lateral facies changes within the Tertiary sedimentary succession were caused by strong regional tectonism developing horst and graben structures (e.g. KARFAKIS \& Doutsos 1995). The onset of the extensional orogenic collapse can be set at the Palaeocene-Eocene boundary (BoNEV et al. 2006) while deeper parts of the Rhodope Massif have experienced at least high-pressure metamorphic conditions still in the Early to Middle Eocene (ca. 55-42 Ma ago), as indicated by metamorphic rims around zircons (LIATI \& Gebauer 1999; Liati 2005). In the late Middle Eocene (ca. $40 \mathrm{Ma}$ ago) the Central Rhodope underwent a metamorphic/fluid event (LIATI 2005) that might indicate the 'peak' of orogenic collapse. Late Eocene uplift in the Eastern Rhodope is clearly shown by ${ }^{40} \mathrm{Ar} /{ }^{39} \mathrm{Ar}$ white-mica cooling ages of ca. $42-35 \mathrm{Ma}$ (e.g. Lips et al. 2000; BonEv 2006). The upper part of the Rhodope nappe pile, including fragments of Vardarian ophiolites, has been eroded supplying sediment to the surrounding foreland including the Tertiary succession of Samothraki. Syn-orogenic extension in the upper part of Rhodope Massif was linked with continued underthrusting in the southern foreland (BONEV et al. 2006) where a contribution of erosion to the exhumation process can not be excluded (LIPS et al. 2000).

\section{Acknowledgements}

Early parts of this work were carried out while GM was holding a PhD scholarship from the German Research Foundation (DFG) and the state of Rhineland-Palatinate through the Graduiertenkolleg 392 "Composition and Evolution of Crust and Mantle". Access to the laboratory facilities at the Max-Planck-Institute for Chemistry and the Institute of Geosciences in Mainz is kindly acknowledged. The first author particularly likes to thank Dr. NiKOLA KogLin, Würzburg, for her assistance in the field, and Prof. Dr. Dimitrios Kostopoulos, Athens, and Prof. Dr. Thomas Reischmann, Mainz, for their stimulating discussions about the geology of Greece. Reviews by Assoc. Prof. Dr. Nikolay Bonev, Sofia, and Prof. Dr. Adamantios KILIAS, Thessaloniki, helped to improve the paper.

\section{References}

Ballhaus, C., Berry, R. F. \& Green, D. H. (1991): High pressure experimental calibration of the olivine-orthopyroxene-spinel oxygen geobarometer: implications for the oxidation state of the upper mantle. - Contributions to Mineralogy and Petrology, 107: 27-40.

BнAтIA, M. R. \& CROOK, K. A. W. (1986): Trace element characteristics of graywackes and tectonic setting discrimination of sedimentary basins. - Contributions to Mineralogy and Petrology, 92: 181-193.

BoNEV, N. (2006): Cenozoic tectonic evolution of the eastern Rhodope massif (Bulgaria): Basement structures and kinematics of syn- to postcollisional extensional deformation. - In: DileK, Y. \& PAVlides, S. (Eds.): Postcollisional tectonics and magmatism in the Mediterranean region and Asia. - Geological Society of America Special Paper, 409, 211-235.

Bonev, N. \& Stampfli, G. (2008a): Petrology, geochemistry and geodynamic implications of Jurassic island arc magmatism as revealed by mafic volcanic rocks in the Mesozoic low-grade sequence, eastern Rhodope, Bulgaria. - Lithos, 100: 210-233.

Bonev, N. \& STAMPFLI, G. (2008b): Gabbro, plagiogranite and associated dykes in the supra-subduction zone Evros Ophiolites, NE Greece. - Geological Magazine, doi:10.1017/S0016756808005396.

Bonev, N., Burg, J.-P. \& Ivanov, Z. (2006): MesozoicTertiary structural evolution of an extensional gneiss dome - the Kesebir-Kardamos dome, eastern Rhodope (Bulgaria-Greece). - International Journal of Earth Sciences, 95: 318-340.

BoUDAGHER-FADEL, M. K. (2002): The relationships between planktonic and larger benthic foraminifera, Middle Miocene to Lower Pliocene facies of Sulawesi. Micropaleontology, 48: 153-176.

- (2008): Evolution and geological significance of larger benthic Foraminifera. - Developments in Palaeontology and Stratigraphy, 21: 544 pp.; Amsterdam (Elsevier).

BouDagher-Fadel, M. K., Noad, J. J. \& Lord, A. R. (2000): Larger Foraminifera from Late Oligocene Earliest Miocene reefal limestones of North East Borneo. - Revista Española de Micropaleontología, 32: 341-362.

Chaproniere, G. C. H. (1975): Palaeoecology of OligoMiocene larger Foraminiferida, Australia. - Alcheringa, 1: $37-58$.

ChRISTODOUlou, G. (1958): Über das Alter einiger Formationen von Samothraki. - Bulletin of the Geological Society of Greece, III (1): 40-45 (in Greek with German summary).

Christofides, G., Koroneos, A., Soldatos, T., EleftheRIADIS, G. \& KiliAs, A. (2001): Eocene magmatism (Sithonia and Elatia plutons) in the Internal Hellenides and implications for Eocene-Miocene geological evolution of the Rhodope Massif (Northern Greece). - Acta Vulcanologica, 13: 73-89.

Christofides, G., Pecskay, Z., Eleftheriadis, G., SoldaTos, T. \& Koroneos, A. (2004): The Tertiary Evros volcanic rocks (Thrace, Northeastern Greece): Petrology and $\mathrm{K} / \mathrm{Ar}$ geochronology. - Geologica Carpathica 55: 397-409. 
CoLe, W. S. (1957): Larger Foraminifera. - U.S. Geological Survey Professional Papers, 280 (I): 321-360.

Cookenboo, H. O., Bustin, R. M. \& Wilks, K. R. (1997): Detrital chromian spinel compositions used to reconstruct the tectonic setting of provenance: implications for orogeny in the Canadian Cordillera. - Journal of Sedimentary Research, 67: 116-123.

Coskun, B. (1997): Oil and gas fields-transfer zone relationships, Thrace basin, NW Turkey. - Marine and Petroleum Geology, 14: 401-416.

DAVIS, E. N. (1963): Der geologische Bau der Insel Samothraki. - Annales géologiques des pays hélleniques, 14: 133-212.

Deer, W. A., Howie, R. A. \& Zussman, J. (1992): An introduction to rock-forming minerals. - 696 pp.; Hong Kong (Longman Group Limited).

Dick, H. J. B. \& Bullen, T. (1984): Chromian spinel as a petrogenetic indicator in abyssal and alpine-type peridotites and spatially associated lavas. - Contributions to Mineralogy and Petrology, 86: 54-76.

DuNHAM, R. J. (1962): Classification of carbonate rock according to depositional texture. - In: Ham, W. E. (Eds.): Classification of carbonate rocks, 108-121; American Association of Petroleum Geologists Memoir no. 1.

Garver, J. I., Royce, P. R. \& Smick, T. A. (1996): Chromium and nickel in shale of the Taconic foreland: a case study for the provenance of fine-grained sediments with an ultramafic source. - Journal of Sedimentary Research, 66: 100-106.

GÖRÜR, N. \& OKAY, A. I. (1996): Fore-arc origin of the Thrace Basin, northwest Turkey. - Geologische Rundschau, 85: 662-668.

HALLOCK, P. \& SCHLAGER, W. (1986): Nutrient excess and the demise of corals reefs and carbonate platform. Palaios, 1: 389-398.

Hatzipanagiotou, K. \& Tsikouras, B. (2001): Rodingite formation from diorite in the Samothraki ophiolite, NE Aegean, Greece. - Geological Journal, 36: 93-109.

HeIMANN, K. O. (1967): Uber das Alter prätertiärer Gesteine des Nordwestteils der Insel Samothraki (Griechenland). - Praktiká tes Akademias Athenon: tu etus Akademia, 42: 153-160.

Heimann, K. O., LebKuchner, H. \& KretZler, W. (1972): Geological map of Greece, Samothraki sheet, scale 1:50000. - Athens (Institute of Geology and Mineral Exploration).

HotTINGer, L. (1983): Processes determining the distribution of larger foraminifera in space and time. Utrecht Micropaleontological Bulletins, 30: 239-253.

JaCobshagen, V. (1986): Geologie von Griechenland. Beiträge zur Regionalen Geologie der Erde, 19: 1-363.

Kamenetsky, V., Crawford, A. J. \& Meffre, S. (2001): Factors controlling chemistry of magmatic spinel: an empirical study of associated olivine, Cr-spinel and melt inclusions from primitive rocks. - Journal of Petrology, 42: 655-671.

KARFAKIS, J. \& DouTsos, T. (1995): Late orogenic evolution of the Circum-Rhodope Belt, Greece. - Neues Jahrbuch für Geologie und Paläontologie, Monatsheft, 5: 305-319.
Kilias, A., Falalakis, G. \& Mountrakis, D. (1999): Cretaceous-Tertiary structures and kinematics of the Serbomacedonian metamorphic rocks and their relation to the exhumation of the Hellenic hinterland (Macedonia, Greece). - International Journal of Earth Sciences, 88: $513-531$.

KoGLIN, N. (2008): Geochemistry, petrogenesis and tectonic setting of ophiolites and mafic-ultramafic complexes in the Northeastern Aegean Region: New traceelement, isotopic and age constraints. - 136 pp.; Ph.D. thesis (University of Mainz, Germany).

Koglin, N., Kostopoulos, D. \& Reischmann, T. (2008): Geochemistry, petrogenesis and tectonic setting of the Samothraki ophiolite, NE Greece: Trace-element, isotopic and zircon age constraints. - Tectonophysics, doi:10.1016/j.tecto.2008.10.028.

Kopp, K. O. (1964): Geologie Thrakiens II: Die Inseln und der Chersones. - Neues Jahrbuch für Geologie und Paläontologie, Abhandlungen, 119: 172-214.

- (1965): Geologie Thrakiens III: Das Tertiär zwischen Rhodope und Evros. - Annales géologiques des pays hélleniques, 16: 315-362.

LiATI, A. (2005): Identification of repeated Alpine (ultra) high-pressure metamorphic events by U-Pb SHRIMP geochronology and REE geochemistry of zircon: the Rhodope zone of Northern Greece. - Contributions to Mineralogy and Petrology, 150: 608-630.

LiaTI, A. \& GEBAUER, D. (1999): Constraining the prograde and retrograde P-T-t- path of Eocene HP rocks by SHRIMP dating of different zircon domains: inferred rates of heating, burial, cooling and exhumation for central Rhodope, northern Greece. - Contributions to Mineralogy and Petrology, 135: 340-354.

Lips, A. L. W., White, S. H. \& WiJBrans, J. R. (2000): Middle-Late Alpine thermostatic evolution of the southern Rhodope Massif, Greece. - Geodinamica Acta, 13: 281-292.

MAGGANAS, A. C. (2002): Constraints on the petrogenesis of Evros ophiolite extrusives, NE Greece. - Lithos, 65: 165-182.

Mc $\overline{\text { LenNan, }}$ S. M., Hemming, S., McDaniel, D. K. \& Hanson, G. N. (1993): Geochemical approaches to sedimentation, provenance, and tectonics. - In: Johnsson, M. J. \& BAsu, A. (Eds.): Processes controlling the composition of clastic sediments. - Geological Society of America Special Paper, 284: 21-40.

Meinhold, G., Kostopoulos, D. \& Reischmann, T. (2007): Geochemical constraints on the provenance and depositional setting of sedimentary rocks from the islands of Chios, Inousses and Psara, Aegean Sea, Greece: implications for the evolution of Palaeotethys. Journal of the Geological Society London, 164: 11451163.

MoRIMOTO, N. (1988): Nomenclature of pyroxenes. - Fortschritte der Mineralogie, 66: 237-252.

Pe-Piper, G. \& Piper, D. J. W. (2002): The igneous rocks of Greece. The anatomy of an orogen. - Beiträge zur regionalen Geologie der Erde, 30: 1-573.

Pe-Piper, G. \& Piper, D. J. W. (2006): Unique features of the Cenozoic igneous rocks of Greece. In: DileK, Y. \& Pavilides, S. (Eds.): Postcollisional tectonics and mag- 
matism in the Mediterranean region and Asia. - Geological Society of America Special Paper, 409: 259-282.

Pober, E. \& Faupl, P. (1988): The chemistry of detrital chromian spinels and its implications for the geodynamic evolution of the Eastern Alps. - Geologische Rundschau, 77: 641-670.

RUDNICK, R. L. \& GAO, S. (2003): Composition of the continental crust. In: RUDNICK, R. L. (Ed.): The Crust. In: Holland, H. D. \& Turekian, K. K. (Eds.): Treatise on Geochemistry; 1-64; Oxford (Elsevier-Pergamon).

Schaub, H. (1981): Nummulites et Assilines de la Téthys paléogène. Taxinomie, phylogénèse et biostratigraphie. Schweizerische Paläontologische Abhandlungen, 104, 105 (atlas I), and 106 (atlas II): 1-236.

Serra-Kiel, J., Hottinger, L., Caus, E., Drobne, K., Ferràndez, C., Jauhri, A. K., Less, G., Pavlovec, R., Pignatti, J., Samsó, J. M., Schaub, H., Sirel, E., Strougo, A., Tambareau, Y., Tosquella, J. \& ZakresVSKAYA, E. (1998): Larger foraminiferal biostratigraphy of the Tethyan Paleocene and Eocene. - Bulletin de la Societé géologique de France, 169: 281-299.

SKAPELIS, N., ECONOMOU, M. \& MichAEL, K. (1987): Geology, petrology and polymetallic ore types in a Tertiary volcanosedimentary terrain, Virini-Pessani-Dadia area, West Thrace (Northern Greece). - Geologica Balcanica, 17: 31-41.

Trevena, A. S. \& Nash, W. P. (1981): An electron microprobe study of detrital feldspar. - Journal of Sedimentary Research, 51: 137-150.

Tsikouras, B. (1992): The ophiolites of the island of Samothrace. - 435 pp.; Ph.D. thesis (University of Patras, Greece) (in Greek with English summary).
Tsikouras, B. \& Hatzipanagiotou, K. (1998): Petrographic evolution of an ophiolite fragment in an ensialic marginal basin, northern Aegean (Samothraki Island, Greece). - European Journal of Mineralogy, 10: 551567.

TsiKouras, B., Pe-Piper, G. \& Hatzipanagiotou, K. (1990): A new date for an ophiolite of the northeastern margin of the Vardar zone, Samothraki, Greece. - Neues Jahrbuch für Mineralogie Monatshefte, 11: 512-527.

von Eynatten, H. \& Gaupp, R. (1999): Provenance of Cretaceous synorogenic sandstones from the Eastern Alps: constraints from framework petrography, heavy mineral analysis, and mineral chemistry. - Sedimentary Geology, 124: 81-111.

ZACHARIADIS, P. (2007): Ophiolites of the eastern Vardar Zone, N. Greece. - 131 pp.; Ph.D. thesis (University of Mainz, Germany).

Manuscript received: June 12, 2008.

Revised version received: November 12, 2008.

Accepted by the Greifswald editor: January 19, 2009.

\section{Addresses of the authors:}

Dr. Guido Meinhold (corresponding author), CASP, Department of Earth Sciences, University of Cambridge, 181a Huntingdon Road, Cambridge CB3 0DH, UK;

e-mail: guido.meinhold@casp.cam.ac.uk

Dr. Marcelle BouDagher-Fadel, Postgraduate Unit of Micropalaeontology, Department of Earth Sciences, University College London, Gower Street, London WC1E 6BT, UK; e-mail: m.fadel@ucl.ac.uk 
Appendix 1. Composition of detrital feldspar from Eocene sandstones of Samothraki.

\begin{tabular}{|c|c|c|c|c|c|c|c|c|c|}
\hline No. & $\mathrm{SiO}_{2}$ & $\mathbf{A l}_{2} \mathbf{O}_{3}$ & $\mathrm{Fe}_{2} \mathrm{O}_{3}$ & $\mathrm{CaO}$ & $\mathrm{Na}_{2} \mathrm{O}$ & $\mathrm{K}_{2} \mathrm{O}$ & $\mathbf{B a O}$ & MgO & Total \\
\hline \multicolumn{10}{|c|}{ Sample S13 } \\
\hline 3 & 68,83 & 18,70 & 0,02 & 0,17 & 11,54 & 0,09 & 0,11 & 0,00 & 99,46 \\
\hline 11 & 69,11 & 18,06 & 0,01 & 0,11 & 11,60 & 0,09 & 0,03 & 0,00 & 99,01 \\
\hline 12 & 67,47 & 18,91 & 0,40 & 0,17 & 11,36 & 0,27 & 0,01 & 0,06 & 98,65 \\
\hline 15 & 68,45 & 18,53 & 0,06 & 0,21 & 11,77 & 0,08 & 0,09 & 0,00 & 99,19 \\
\hline 16 & 67,74 & 18,70 & 0,00 & 0,47 & 11,65 & 0,04 & 0,03 & 0,00 & 98,63 \\
\hline 17 & 67,39 & 17,62 & 1,86 & 0,12 & 11,15 & 0,10 & 0,07 & 0,06 & 98,37 \\
\hline 18 & 67,71 & 18,90 & 0,12 & 0,56 & 11,41 & 0,07 & 0,01 & 0,00 & 98,78 \\
\hline 22 & 68,40 & 18,55 & 0,12 & 0,19 & 11,75 & 0,05 & 0,09 & 0,01 & 99,16 \\
\hline 23 & 69,44 & 18,30 & 0,16 & 0,05 & 11,82 & 0,06 & 0,03 & 0,00 & 99,86 \\
\hline 24 & 67,65 & 19,09 & 0,05 & 0,18 & 11,79 & 0,27 & 0,01 & 0,03 & 99,08 \\
\hline 25 & 68,72 & 18,34 & 0,18 & 0,12 & 11,64 & 0,03 & 0,09 & 0,03 & 99,14 \\
\hline 26 & 68,73 & 18,47 & 0,08 & 0,07 & 11,98 & 0,04 & 0,00 & 0,00 & 99,36 \\
\hline 31 & 67,60 & 18,69 & 0,70 & 0,24 & 11,37 & 0,13 & 0,04 & 0,16 & 98,93 \\
\hline 34 & 68,52 & 18,49 & 0,20 & 0,12 & 11,53 & 0,23 & 0,01 & 0,01 & 99,11 \\
\hline 37 & 67,81 & 18,71 & 0,29 & 0,57 & 11,50 & 0,09 & 0,00 & 0,02 & 98,99 \\
\hline 39 & 63,90 & 20,97 & 0,31 & 0,25 & 9,57 & 2,26 & 0,06 & 0,31 & 97,64 \\
\hline 40 & 68,53 & 18,13 & 0,06 & 0,08 & 11,72 & 0,02 & 0,02 & 0,01 & 98,57 \\
\hline 45 & 68,54 & 18,21 & 0,00 & 0,03 & 11,69 & 0,01 & 0,00 & 0,00 & 98,48 \\
\hline 47 & 68,12 & 17,88 & 0,11 & 0,22 & 11,18 & 0,02 & 0,00 & 0,00 & 97,53 \\
\hline 49 & 67,71 & 19,20 & 0,13 & 0,93 & 11,12 & 0,08 & 0,00 & 0,01 & 99,18 \\
\hline 50 & 67,55 & 18,46 & 0,03 & 0,28 & 11,93 & 0,05 & 0,04 & 0,00 & 98,33 \\
\hline 52 & 68,93 & 18,50 & 0,00 & 0,21 & 11,71 & 0,06 & 0,06 & 0,00 & 99,47 \\
\hline 55 & 68,55 & 18,64 & 0,03 & 0,16 & 11,92 & 0,03 & 0,00 & 0,00 & 99,34 \\
\hline 57 & 67,20 & 18,96 & 0,13 & 0,74 & 11,25 & 0,25 & 0,02 & 0,00 & 98,55 \\
\hline 62 & 67,80 & 18,42 & 0,07 & 0,32 & 11,85 & 0,04 & 0,02 & 0,00 & 98,52 \\
\hline 63 & 67,45 & 18,79 & 0,58 & 0,62 & 11,32 & 0,22 & 0,06 & 0,01 & 99,05 \\
\hline 68 & 67,89 & 18,54 & 0,07 & 0,25 & 11,72 & 0,19 & 0,15 & 0,00 & 98,81 \\
\hline 69 & 68,36 & 18,51 & 0,09 & 0,02 & 12,10 & 0,00 & 0,00 & 0,00 & 99,08 \\
\hline 72 & 68,01 & 18,68 & 0,07 & 0,39 & 11,75 & 0,04 & 0,06 & 0,00 & 99,00 \\
\hline 73 & 68,45 & 18,57 & 0,09 & 0,25 & 11,55 & 0,10 & 0,00 & 0,00 & 99,02 \\
\hline 78 & 67,20 & 18,19 & 0,08 & 0,18 & 11,47 & 0,14 & 0,00 & 0,03 & 97,29 \\
\hline 85 & 67,58 & 18,44 & 0,14 & 0,15 & 11,65 & 0,06 & 0,02 & 0,00 & 98,04 \\
\hline 86 & 68,09 & 18,76 & 0,15 & 0,21 & 11,71 & 0,15 & 0,04 & 0,03 & 99,14 \\
\hline 94 & 68,29 & 18,74 & 0,15 & 0,14 & 11,66 & 0,11 & 0,00 & 0,01 & 99,11 \\
\hline 96 & 67,83 & 18,89 & 0,15 & 0,60 & 11,64 & 0,16 & 0,00 & 0,00 & 99,27 \\
\hline 97 & 68,24 & 18,30 & 0,11 & 0,19 & 11,58 & 0,15 & 0,14 & 0,00 & 98,71 \\
\hline 98 & 68,23 & 18,12 & 0,10 & 0,34 & 11,61 & 0,02 & 0,00 & 0,00 & 98,41 \\
\hline 99 & 65,02 & 17,94 & 3,74 & 0,32 & 10,42 & 0,18 & 0,00 & 0,37 & 97,99 \\
\hline 101 & 68,40 & 18,48 & 0,28 & 0,39 & 11,42 & 0,10 & 0,00 & 0,01 & 99,08 \\
\hline 103 & 68,15 & 19,13 & 0,01 & 0,56 & 11,57 & 0,05 & 0,03 & 0,01 & 99,51 \\
\hline 106 & 66,48 & 17,93 & 1,44 & 0,21 & 10,29 & 0,70 & 0,11 & 0,09 & 97,25 \\
\hline 109 & 68,72 & 18,03 & 0,00 & 0,14 & 11,46 & 0,03 & 0,02 & 0,02 & 98,41 \\
\hline 110 & 69,10 & 18,79 & 0,13 & 0,30 & 9,95 & 0,06 & 0,01 & 0,00 & 98,34 \\
\hline \multicolumn{10}{|c|}{ Sample S16 } \\
\hline 116 & 68,08 & 18,30 & 0,04 & 0,14 & 11,78 & 0,02 & 0,00 & 0,00 & 98,35 \\
\hline 117 & 68,21 & 18,44 & 0,05 & 0,26 & 11,76 & 0,08 & 0,07 & 0,03 & 98,90 \\
\hline 121 & 67,98 & 18,68 & 0,02 & 0,34 & 11,64 & 0,08 & 0,00 & 0,01 & 98,74 \\
\hline 122 & 67,28 & 19,28 & 0,15 & 0,88 & 11,76 & 0,13 & 0,00 & 0,00 & 99,47 \\
\hline 123 & 68,32 & 18,27 & 0,08 & 0,10 & 11,86 & 0,05 & 0,00 & 0,00 & 98,68 \\
\hline 124 & 68,85 & 18,48 & 0,03 & 0,12 & 12,06 & 0,10 & 0,00 & 0,01 & 99,65 \\
\hline 125 & 69,03 & 18,34 & 0,06 & 0,18 & 11,53 & 0,09 & 0,00 & 0,01 & 99,25 \\
\hline
\end{tabular}


Appendix 1 (cont.)

\begin{tabular}{|c|c|c|c|c|c|c|c|c|c|}
\hline 126 & 68,52 & 18,09 & 0,12 & 0,08 & 11,43 & 0,15 & 0,04 & 0,00 & 98,43 \\
\hline 129 & 64,96 & 20,63 & 0,03 & 2,45 & 10,66 & 0,07 & 0,07 & 0,00 & 98,87 \\
\hline 130 & 68,20 & 18,56 & 0,03 & 0,30 & 11,60 & 0,08 & 0,01 & 0,00 & 98,78 \\
\hline 131 & 67,93 & 18,88 & 0,02 & 0,62 & 11,52 & 0,13 & 0,02 & 0,01 & 99,13 \\
\hline 135 & 67,35 & 18,50 & 0,09 & 0,62 & 10,95 & 0,09 & 0,05 & 0,00 & 97,65 \\
\hline 137 & 66,31 & 18,90 & 1,31 & 0,26 & 10,81 & 0,25 & 0,03 & 0,71 & 98,56 \\
\hline 138 & 67,89 & 19,03 & 0,10 & 0,55 & 11,22 & 0,26 & 0,00 & 0,00 & 99,05 \\
\hline 140 & 67,98 & 18,43 & 0,03 & 0,23 & 11,68 & 0,02 & 0,00 & 0,00 & 98,37 \\
\hline 141 & 68,45 & 18,55 & 0,11 & 0,23 & 11,80 & 0,10 & 0,00 & 0,01 & 99,25 \\
\hline 143 & 66,84 & 19,12 & 0,12 & 0,19 & 11,14 & 0,61 & 0,05 & 0,04 & 98,10 \\
\hline 144 & 68,06 & 18,60 & 0,04 & 0,20 & 11,74 & 0,06 & 0,06 & 0,01 & 98,77 \\
\hline 145 & 68,41 & 18,62 & 0,08 & 0,33 & 11,72 & 0,06 & 0,00 & 0,00 & 99,22 \\
\hline 146 & 68,55 & 18,54 & 0,22 & 0,31 & 11,67 & 0,03 & 0,00 & 0,03 & 99,35 \\
\hline 147 & 67,28 & 17,99 & 0,01 & 0,47 & 11,06 & 0,10 & 0,01 & 0,01 & 96,93 \\
\hline 149 & 68,46 & 18,43 & 0,15 & 0,15 & 11,96 & 0,11 & 0,00 & 0,00 & 99,25 \\
\hline 151 & 68,18 & 18,68 & 0,09 & 0,33 & 11,56 & 0,12 & 0,00 & 0,02 & 98,98 \\
\hline 152 & 68,65 & 18,51 & 0,00 & 0,05 & 12,00 & 0,04 & 0,04 & 0,00 & 99,29 \\
\hline 153 & 68,35 & 19,38 & 0,09 & 0,72 & 11,48 & 0,05 & 0,06 & 0,00 & 100,13 \\
\hline 154 & 64,42 & 21,37 & 0,45 & 0,12 & 9,09 & 2,35 & 0,00 & 0,10 & 97,90 \\
\hline 155 & 67,86 & 18,95 & 0,03 & 0,73 & 11,45 & 0,12 & 0,05 & 0,02 & 99,21 \\
\hline 156 & 67,37 & 18,92 & 0,10 & 0,30 & 11,40 & 0,30 & 0,00 & 0,00 & 98,39 \\
\hline 157 & 67,69 & 18,94 & 0,05 & 0,51 & 11,42 & 0,05 & 0,09 & 0,02 & 98,76 \\
\hline 158 & 68,43 & 18,49 & 0,00 & 0,15 & 11,67 & 0,06 & 0,03 & 0,00 & 98,82 \\
\hline 159 & 67,30 & 18,65 & 0,11 & 0,49 & 11,43 & 0,05 & 0,01 & 0,00 & 98,04 \\
\hline 160 & 66,05 & 19,74 & 0,13 & 1,51 & 11,02 & 0,05 & 0,03 & 0,00 & 98,53 \\
\hline 161 & 66,13 & 20,16 & 0,09 & 0,40 & 10,83 & 0,90 & 0,01 & 0,06 & 98,59 \\
\hline 162 & 67,94 & 18,62 & 0,08 & 0,36 & 11,48 & 0,12 & 0,02 & 0,02 & 98,65 \\
\hline 165 & 65,17 & 20,48 & 0,25 & 2,45 & 10,02 & 0,10 & 0,03 & 0,00 & 98,50 \\
\hline 166 & 68,13 & 19,05 & 0,13 & 0,48 & 11,60 & 0,12 & 0,01 & 0,01 & 99,53 \\
\hline 167 & 67,43 & 18,46 & 1,12 & 0,14 & 11,57 & 0,04 & 0,03 & 0,00 & 98,79 \\
\hline 168 & 68,18 & 18,35 & 0,11 & 0,11 & 11,53 & 0,08 & 0,00 & 0,00 & 98,36 \\
\hline 171 & 68,12 & 18,45 & 0,09 & 0,19 & 11,57 & 0,07 & 0,01 & 0,03 & 98,52 \\
\hline 173 & 68,44 & 18,13 & 0,06 & 0,10 & 11,77 & 0,03 & 0,00 & 0,02 & 98,55 \\
\hline 174 & 68,44 & 18,56 & 0,10 & 0,14 & 11,67 & 0,08 & 0,02 & 0,00 & 99,01 \\
\hline 175 & 67,30 & 18,81 & 0,00 & 0,67 & 11,03 & 0,10 & 0,06 & 0,00 & 97,96 \\
\hline 176 & 68,67 & 18,34 & 0,00 & 0,10 & 11,92 & 0,06 & 0,00 & 0,00 & 99,09 \\
\hline 177 & 67,49 & 18,91 & 0,00 & 0,62 & 11,23 & 0,08 & 0,07 & 0,00 & 98,40 \\
\hline 178 & 67,98 & 18,88 & 0,12 & 0,52 & 11,27 & 0,07 & 0,00 & 0,02 & 98,86 \\
\hline 179 & 68,16 & 18,68 & 0,14 & 0,33 & 11,66 & 0,11 & 0,00 & 0,00 & 99,08 \\
\hline 180 & 68,06 & 18,56 & 0,00 & 0,14 & 11,81 & 0,06 & 0,07 & 0,00 & 98,70 \\
\hline 181 & 68,70 & 18,39 & 0,05 & 0,12 & 12,01 & 0,03 & 0,05 & 0,00 & 99,35 \\
\hline 182 & 67,63 & 18,26 & 0,00 & 0,14 & 11,54 & 0,08 & 0,06 & 0,01 & 97,72 \\
\hline 184 & 67,75 & 18,75 & 0,08 & 0,55 & 11,45 & 0,12 & 0,04 & 0,00 & 98,73 \\
\hline
\end{tabular}


Appendix 2. Composition of detrital chrome spinel from Eocene sandstones of Samothraki.

\begin{tabular}{|c|c|c|c|c|c|c|c|c|c|c|c|}
\hline No. & $\mathrm{TiO}_{2}$ & $\mathbf{A l}_{2} \mathbf{O}_{3}$ & $\mathrm{Cr}_{2} \mathrm{O}_{3}$ & $\mathrm{FeO}$ & $\mathrm{MnO}$ & MgO & NiO & $\mathrm{V}_{2} \mathrm{O}_{3}$ & $\mathrm{ZnO}$ & $\mathrm{CoO}$ & Total \\
\hline \multicolumn{12}{|c|}{ Sample S13 } \\
\hline 1 & 0,02 & 21,34 & 44,22 & 25,15 & 0,35 & 8,93 & 0,10 & 0,31 & 0,55 & 0,13 & 101,09 \\
\hline 2 & 0,10 & 12,89 & 50,84 & 28,23 & 0,43 & 7,01 & 0,06 & 0,28 & 0,50 & 0,07 & 100,39 \\
\hline 3 & 0,05 & 32,79 & 34,27 & 20,87 & 0,17 & 11,39 & 0,14 & 0,14 & 0,84 & 0,17 & 100,82 \\
\hline 4 & 0,05 & 29,41 & 38,26 & 17,87 & 0,15 & 14,23 & 0,13 & 0,25 & 0,16 & 0,05 & 100,56 \\
\hline 6 & 0,08 & 22,61 & 45,87 & 17,76 & 0,18 & 13,22 & 0,09 & 0,15 & 0,17 & 0,06 & 100,18 \\
\hline 7 & 0,13 & 29,10 & 38,37 & 18,63 & 0,16 & 13,42 & 0,11 & 0,23 & 0,20 & 0,04 & 100,38 \\
\hline 8 & 0,18 & 8,89 & 54,32 & 29,33 & 0,32 & 6,50 & 0,03 & 0,15 & 0,50 & 0,11 & 100,32 \\
\hline 9 & 0,31 & 16,76 & 42,40 & 33,32 & 0,35 & 6,33 & 0,02 & 0,29 & 0,46 & 0,09 & 100,33 \\
\hline 10 & 0,13 & 24,46 & 44,59 & 17,32 & 0,21 & 13,57 & 0,09 & 0,26 & 0,19 & 0,08 & 100,90 \\
\hline 11 & 0,12 & 18,16 & 51,02 & 18,37 & 0,20 & 12,61 & 0,07 & 0,24 & 0,08 & 0,10 & 100,96 \\
\hline 12 & 0,40 & 16,78 & 46,77 & 28,06 & 0,36 & 7,19 & 0,05 & 0,22 & 0,40 & 0,11 & 100,34 \\
\hline 13 & 0,24 & 13,87 & 49,36 & 29,03 & 0,32 & 6,95 & 0,03 & 0,15 & 0,23 & 0,11 & 100,30 \\
\hline 14 & 0,26 & 15,95 & 47,55 & 28,22 & 0,32 & 7,46 & 0,06 & 0,17 & 0,41 & 0,13 & 100,53 \\
\hline 15 & 0,22 & 17,79 & 38,64 & 36,14 & 0,33 & 5,73 & 0,07 & 0,24 & 0,74 & 0,17 & 100,06 \\
\hline 16 & 0,23 & 22,99 & 43,10 & 21,98 & 0,26 & 11,65 & 0,09 & 0,18 & 0,17 & 0,06 & 100,71 \\
\hline 17 & 0,09 & 26,15 & 40,44 & 21,66 & 0,21 & 11,63 & 0,12 & 0,22 & 0,23 & 0,06 & 100,80 \\
\hline 18 & 0,08 & 36,84 & 32,35 & 14,02 & 0,14 & 16,74 & 0,18 & 0,17 & 0,09 & 0,09 & 100,71 \\
\hline 19 & 0,07 & 25,21 & 41,77 & 22,35 & 0,24 & 10,04 & 0,07 & 0,22 & 0,41 & 0,11 & 100,47 \\
\hline 20 & 0,44 & 28,67 & 37,02 & 17,53 & 0,17 & 16,22 & 0,14 & 0,16 & 0,12 & 0,08 & 100,55 \\
\hline 21 & 0,06 & 28,11 & 37,15 & 22,10 & 0,19 & 12,16 & 0,13 & 0,23 & 0,24 & 0,07 & 100,43 \\
\hline 22 & 0,08 & 27,23 & 41,21 & 20,36 & 0,20 & 11,10 & 0,05 & 0,23 & 0,45 & 0,13 & 101,04 \\
\hline 23 & 0,15 & 17,12 & 51,10 & 22,11 & 0,32 & 9,26 & 0,04 & 0,27 & 0,26 & 0,07 & 100,70 \\
\hline 24 & 0,02 & 33,89 & 34,38 & 17,36 & 0,20 & 14,28 & 0,14 & 0,19 & 0,25 & 0,05 & 100,76 \\
\hline 25 & 0,06 & 23,88 & 41,26 & 24,37 & 0,32 & 9,83 & 0,10 & 0,27 & 0,29 & 0,11 & 100,50 \\
\hline 26 & 0,06 & 23,69 & 44,24 & 20,40 & 0,23 & 11,30 & 0,04 & 0,23 & 0,26 & 0,06 & 100,51 \\
\hline 27 & 0,11 & 23,36 & 45,77 & 17,59 & 0,12 & 13,48 & 0,12 & 0,28 & 0,16 & 0,07 & 101,06 \\
\hline 28 & 0,04 & 17,52 & 47,26 & 25,12 & 0,28 & 9,85 & 0,12 & 0,31 & 0,22 & 0,06 & 100,78 \\
\hline 29 & 0,05 & 26,04 & 41,40 & 22,14 & 0,27 & 10,39 & 0,08 & 0,26 & 0,35 & 0,08 & 101,05 \\
\hline 30 & 0,07 & 27,77 & 40,26 & 19,25 & 0,19 & 13,13 & 0,11 & 0,25 & 0,18 & 0,10 & 101,30 \\
\hline 31 & 0,04 & 23,41 & 45,00 & 19,05 & 0,27 & 12,78 & 0,07 & 0,26 & 0,24 & 0,05 & 101,18 \\
\hline 32 & 0,04 & 31,22 & 36,36 & 17,78 & 0,14 & 14,79 & 0,12 & 0,25 & 0,19 & 0,08 & 100,96 \\
\hline 33 & 0,13 & 34,53 & 28,98 & 26,48 & 0,24 & 10,07 & 0,13 & 0,21 & 0,40 & 0,11 & 101,28 \\
\hline 34 & 0,10 & 17,86 & 47,46 & 25,87 & 0,26 & 8,55 & 0,02 & 0,29 & 0,55 & 0,14 & 101,10 \\
\hline 35 & 0,26 & 14,60 & 40,69 & 38,71 & 0,33 & 4,72 & 0,06 & 0,27 & 0,45 & 0,11 & 100,21 \\
\hline
\end{tabular}


Appendix 2 (cont.)

\begin{tabular}{|c|c|c|c|c|c|c|c|c|c|c|c|}
\hline 36 & 0,07 & 29,08 & 37,19 & 22,53 & 0,20 & 11,68 & 0,09 & 0,20 & 0,54 & 0,11 & 101,68 \\
\hline 37 & 0,11 & 19,05 & 46,60 & 22,70 & 0,23 & 11,55 & 0,11 & 0,32 & 0,18 & 0,07 & 100,93 \\
\hline 38 & 0,09 & 20,61 & 45,86 & 23,83 & 0,23 & 9,76 & 0,06 & 0,24 & 0,33 & 0,10 & 101,10 \\
\hline 39 & 0,03 & 28,89 & 40,08 & 17,05 & 0,17 & 14,12 & 0,09 & 0,23 & 0,27 & 0,03 & 100,96 \\
\hline 40 & 0,06 & 24,35 & 42,55 & 22,63 & 0,17 & 10,55 & 0,06 & 0,31 & 0,53 & 0,11 & 101,32 \\
\hline 41 & 0,25 & 22,73 & 37,96 & 30,19 & 0,29 & 8,25 & 0,10 & 0,25 & 0,67 & 0,09 & 100,78 \\
\hline 42 & 0,06 & 23,40 & 44,80 & 19,59 & 0,16 & 12,18 & 0,10 & 0,24 & 0,20 & 0,05 & 100,77 \\
\hline 43 & 0,02 & 21,74 & 46,99 & 19,01 & 0,24 & 12,65 & 0,07 & 0,21 & 0,14 & 0,10 & 101,17 \\
\hline 44 & 0,13 & 26,85 & 41,43 & 20,41 & 0,21 & 10,94 & 0,08 & 0,23 & 0,53 & 0,06 & 100,88 \\
\hline 45 & 0,07 & 32,01 & 36,98 & 16,52 & 0,14 & 14,91 & 0,09 & 0,19 & 0,16 & 0,06 & 101,13 \\
\hline 47 & 0,07 & 35,72 & 32,49 & 17,22 & 0,12 & 14,84 & 0,15 & 0,18 & 0,15 & 0,07 & 101,00 \\
\hline 48 & 0,15 & 26,43 & 42,86 & 17,48 & 0,16 & 13,59 & 0,08 & 0,22 & 0,18 & 0,06 & 101,20 \\
\hline 49 & 0,06 & 32,11 & 34,63 & 19,58 & 0,17 & 13,44 & 0,11 & 0,19 & 0,26 & 0,06 & 100,61 \\
\hline 50 & 0,08 & 29,43 & 38,61 & 20,29 & 0,26 & 11,77 & 0,07 & 0,20 & 0,27 & 0,09 & 101,06 \\
\hline 52 & 0,12 & 28,56 & 37,99 & 21,28 & 0,20 & 11,55 & 0,09 & 0,24 & 0,56 & 0,09 & 100,68 \\
\hline 53 & 0,09 & 32,08 & 36,47 & 17,57 & 0,16 & 14,22 & 0,12 & 0,21 & 0,24 & 0,07 & 101,22 \\
\hline 55 & 0,40 & 34,22 & 27,11 & 28,37 & 0,21 & 9,28 & 0,09 & 0,32 & 0,33 & 0,10 & 100,43 \\
\hline 56 & 0,05 & 29,03 & 39,72 & 17,54 & 0,14 & 14,15 & 0,12 & 0,26 & 0,21 & 0,09 & 101,32 \\
\hline 57 & 0,07 & 32,83 & 36,06 & 15,99 & 0,13 & 15,27 & 0,16 & 0,21 & 0,16 & 0,07 & 100,94 \\
\hline 58 & 0,12 & 12,70 & 56,74 & 19,69 & 0,24 & 10,86 & 0,04 & 0,27 & 0,15 & 0,06 & 100,87 \\
\hline 59 & 0,36 & 15,09 & 42,70 & 35,10 & 0,36 & 5,41 & 0,07 & 0,26 & 0,50 & 0,09 & 99,93 \\
\hline 60 & 0,36 & 13,76 & 43,13 & 37,38 & 0,46 & 4,19 & 0,08 & 0,22 & 0,55 & 0,11 & 100,24 \\
\hline 61 & 0,41 & 7,05 & 39,62 & 45,02 & 0,27 & 5,07 & 0,18 & 0,41 & 0,25 & 0,08 & 98,35 \\
\hline 62 & 0,52 & 17,35 & 42,02 & 33,75 & 0,42 & 5,88 & 0,09 & 0,28 & 0,35 & 0,10 & 100,76 \\
\hline 64 & 0,39 & 31,79 & 32,50 & 26,27 & 0,56 & 8,56 & 0,13 & 0,16 & 0,51 & 0,07 & 100,94 \\
\hline 65 & 0,13 & 9,16 & 59,51 & 21,68 & 0,24 & 9,74 & 0,07 & 0,13 & 0,19 & 0,12 & 100,96 \\
\hline 66 & 0,19 & 11,57 & 50,67 & 29,78 & 0,34 & 7,10 & 0,05 & 0,18 & 0,31 & 0,10 & 100,29 \\
\hline 67 & 0,05 & 17,64 & 50,29 & 24,07 & 0,26 & 8,35 & 0,04 & 0,24 & 0,58 & 0,12 & 101,64 \\
\hline 68 & 0,14 & 27,18 & 40,02 & 21,18 & 0,21 & 11,38 & 0,09 & 0,25 & 0,44 & 0,12 & 101,01 \\
\hline 69 & 0,56 & 32,10 & 33,55 & 17,10 & 0,13 & 16,71 & 0,11 & 0,22 & 0,08 & 0,03 & 100,59 \\
\hline 70 & 0,22 & 12,64 & 55,44 & 21,77 & 0,27 & 10,04 & 0,08 & 0,20 & 0,23 & 0,10 & 100,99 \\
\hline 71 & 0,06 & 32,57 & 35,76 & 16,80 & 0,22 & 14,70 & 0,13 & 0,28 & 0,17 & 0,07 & 100,75 \\
\hline 72 & 0,03 & 29,74 & 39,05 & 17,03 & 0,15 & 14,63 & 0,15 & 0,23 & 0,16 & 0,10 & 101,26 \\
\hline 73 & 0,05 & 28,00 & 40,65 & 17,53 & 0,16 & 13,34 & 0,08 & 0,21 & 0,21 & 0,08 & 100,29 \\
\hline 74 & 0,14 & 26,08 & 42,40 & 17,15 & 0,18 & 13,91 & 0,10 & 0,25 & 0,16 & 0,04 & 100,39 \\
\hline 75 & 0,13 & 28,47 & 40,28 & 16,81 & 0,15 & 14,50 & 0,12 & 0,21 & 0,22 & 0,08 & 100,96 \\
\hline 76 & 0,05 & 32,54 & 33,20 & 20,08 & 0,20 & 13,55 & 0,13 & 0,26 & 0,26 & 0,09 & 100,37 \\
\hline 77 & 0,02 & 29,69 & 36,90 & 17,91 & 0,12 & 14,57 & 0,14 & 0,21 & 0,15 & 0,07 & 99,77 \\
\hline
\end{tabular}


Appendix 2 (cont.)

\begin{tabular}{|c|c|c|c|c|c|c|c|c|c|c|c|}
\hline 78 & 0,15 & 12,45 & 56,99 & 20,53 & 0,26 & 9,62 & 0,04 & 0,05 & 0,22 & 0,08 & 100,39 \\
\hline 79 & 0,12 & 32,86 & 35,16 & 18,51 & 0,25 & 13,53 & 0,15 & 0,20 & 0,24 & 0,11 & 101,13 \\
\hline 80 & 0,03 & 21,68 & 43,57 & 24,99 & 0,26 & 8,41 & 0,00 & 0,26 & 0,59 & 0,10 & 99,89 \\
\hline 81 & 0,12 & 26,14 & 43,14 & 17,35 & 0,19 & 13,87 & 0,10 & 0,26 & 0,19 & 0,06 & 101,41 \\
\hline 82 & 0,10 & 18,21 & 50,89 & 19,57 & 0,24 & 11,58 & 0,09 & 0,19 & 0,20 & 0,08 & 101,14 \\
\hline 83 & 0,31 & 40,13 & 26,49 & 16,59 & 0,25 & 16,57 & 0,25 & 0,16 & 0,09 & 0,05 & 100,88 \\
\hline 84 & 0,21 & 28,06 & 41,22 & 16,96 & 0,13 & 14,03 & 0,08 & 0,23 & 0,19 & 0,08 & 101,18 \\
\hline 85 & 0,07 & 25,57 & 42,38 & 20,16 & 0,23 & 11,98 & 0,07 & 0,26 & 0,22 & 0,10 & 101,02 \\
\hline 86 & 0,13 & 25,43 & 44,05 & 16,61 & 0,13 & 14,05 & 0,08 & 0,19 & 0,19 & 0,08 & 100,94 \\
\hline 87 & 0,08 & 25,22 & 42,84 & 19,53 & 0,17 & 12,54 & 0,06 & 0,21 & 0,22 & 0,08 & 100,95 \\
\hline 88 & 0,33 & 39,03 & 29,32 & 15,32 & 0,11 & 15,86 & 0,16 & 0,15 & 0,28 & 0,11 & 100,68 \\
\hline 89 & 0,07 & 24,37 & 45,60 & 16,79 & 0,22 & 13,49 & 0,07 & 0,23 & 0,18 & 0,05 & 101,06 \\
\hline 90 & 0,13 & 30,95 & 36,95 & 17,41 & 0,20 & 14,39 & 0,11 & 0,12 & 0,21 & 0,09 & 100,55 \\
\hline 91 & 0,05 & 28,76 & 40,40 & 18,69 & 0,16 & 12,88 & 0,11 & 0,25 & 0,21 & 0,07 & 101,59 \\
\hline 92 & 0,18 & 8,99 & 50,13 & 33,96 & 0,45 & 5,13 & 0,07 & 0,10 & 0,29 & 0,06 & 99,38 \\
\hline 93 & 0,03 & 29,99 & 36,72 & 21,74 & 0,25 & 11,27 & 0,10 & 0,17 & 0,28 & 0,08 & 100,63 \\
\hline 94 & 0,11 & 12,57 & 52,83 & 25,26 & 0,38 & 7,99 & 0,03 & 0,22 & 0,32 & 0,12 & 99,83 \\
\hline 95 & 0,07 & 34,29 & 35,20 & 15,29 & 0,13 & 15,50 & 0,14 & 0,15 & 0,16 & 0,07 & 101,00 \\
\hline 96 & 0,08 & 19,34 & 46,49 & 23,91 & 0,19 & 9,28 & 0,03 & 0,30 & 0,45 & 0,09 & 100,15 \\
\hline 97 & 0,05 & 23,55 & 43,89 & 22,42 & 0,22 & 10,27 & 0,06 & 0,27 & 0,30 & 0,08 & 101,09 \\
\hline 99 & 0,05 & 23,64 & 45,87 & 17,51 & 0,20 & 12,96 & 0,08 & 0,19 & 0,23 & 0,05 & 100,77 \\
\hline \multicolumn{12}{|c|}{ Sample S15 } \\
\hline 100 & 0,47 & 41,34 & 24,50 & 14,63 & 0,10 & 18,14 & 0,23 & 0,13 & 0,12 & 0,04 & 99,70 \\
\hline 101 & 0,13 & 10,38 & 58,09 & 21,42 & 0,29 & 9,21 & 0,00 & 0,38 & 0,22 & 0,10 & 100,21 \\
\hline 102 & 0,04 & 29,88 & 39,12 & 16,61 & 0,22 & 14,87 & 0,11 & 0,21 & 0,13 & 0,07 & 101,27 \\
\hline 103 & 0,06 & 21,65 & 43,26 & 25,37 & 0,28 & 9,58 & 0,07 & 0,28 & 0,38 & 0,08 & 101,01 \\
\hline 104 & 0,09 & 21,80 & 46,20 & 21,08 & 0,18 & 11,25 & 0,02 & 0,24 & 0,25 & 0,08 & 101,19 \\
\hline 105 & 0,03 & 25,18 & 44,35 & 17,60 & 0,17 & 13,13 & 0,09 & 0,22 & 0,17 & 0,05 & 100,99 \\
\hline 106 & 0,27 & 10,93 & 55,27 & 26,67 & 0,33 & 6,55 & 0,00 & 0,20 & 0,40 & 0,12 & 100,75 \\
\hline 107 & 0,14 & 29,44 & 39,89 & 16,18 & 0,20 & 14,79 & 0,06 & 0,21 & 0,17 & 0,06 & 101,14 \\
\hline 108 & 0,30 & 14,01 & 47,92 & 29,24 & 0,42 & 7,61 & 0,03 & 0,17 & 0,20 & 0,09 & 100,00 \\
\hline 109 & 0,10 & 21,95 & 45,96 & 18,90 & 0,16 & 12,58 & 0,08 & 0,21 & 0,18 & 0,09 & 100,22 \\
\hline 110 & 0,04 & 33,07 & 35,49 & 16,52 & 0,16 & 15,00 & 0,13 & 0,24 & 0,18 & 0,05 & 100,88 \\
\hline 111 & 0,13 & 13,20 & 53,58 & 24,66 & 0,36 & 7,86 & 0,02 & 0,23 & 0,35 & 0,08 & 100,46 \\
\hline 112 & 0,06 & 11,38 & 52,76 & 26,93 & 0,34 & 8,03 & 0,08 & 0,20 & 0,29 & 0,11 & 100,18 \\
\hline 113 & 0,23 & 13,91 & 53,04 & 24,34 & 0,36 & 8,28 & 0,05 & 0,22 & 0,56 & 0,07 & 101,05 \\
\hline 114 & 0,08 & 21,28 & 47,05 & 18,85 & 0,18 & 12,46 & 0,09 & 0,25 & 0,15 & 0,05 & 100,44 \\
\hline 115 & 0,11 & 23,83 & 44,64 & 18,65 & 0,23 & 12,72 & 0,09 & 0,24 & 0,14 & 0,02 & 100,67 \\
\hline
\end{tabular}


Appendix 2 (cont.)

\begin{tabular}{|c|c|c|c|c|c|c|c|c|c|c|c|}
\hline 116 & 0,25 & 14,96 & 48,11 & 28,47 & 0,32 & 8,06 & 0,06 & 0,17 & 0,24 & 0,12 & 100,76 \\
\hline 117 & 0,10 & 24,88 & 43,91 & 17,24 & 0,21 & 14,18 & 0,12 & 0,23 & 0,11 & 0,07 & 101,04 \\
\hline 118 & 0,24 & 25,47 & 43,55 & 17,57 & 0,14 & 13,42 & 0,06 & 0,23 & 0,23 & 0,09 & 101,00 \\
\hline 119 & 0,24 & 10,11 & 49,64 & 32,20 & 0,40 & 6,41 & 0,07 & 0,14 & 0,43 & 0,12 & 99,76 \\
\hline 120 & 0,19 & 23,05 & 41,00 & 25,84 & 0,27 & 9,51 & 0,08 & 0,22 & 0,24 & 0,09 & 100,48 \\
\hline 121 & 0,18 & 25,31 & 43,05 & 19,56 & 0,20 & 11,93 & 0,04 & 0,26 & 0,35 & 0,12 & 101,00 \\
\hline 122 & 0,33 & 18,71 & 48,21 & 23,93 & 0,25 & 8,61 & 0,03 & 0,32 & 0,39 & 0,08 & 100,87 \\
\hline 123 & 0,26 & 23,55 & 39,56 & 26,63 & 0,26 & 9,56 & 0,14 & 0,28 & 0,27 & 0,08 & 100,58 \\
\hline 124 & 0,08 & 32,62 & 35,99 & 16,58 & 0,19 & 14,85 & 0,11 & 0,17 & 0,21 & 0,11 & 100,91 \\
\hline 125 & 0,12 & 24,91 & 38,56 & 25,21 & 0,28 & 10,89 & 0,12 & 0,28 & 0,23 & 0,11 & 100,71 \\
\hline 126 & 0,41 & 15,94 & 44,61 & 32,20 & 0,38 & 6,02 & 0,23 & 0,27 & 0,32 & 0,10 & 100,48 \\
\hline 127 & 0,01 & 30,61 & 37,72 & 18,11 & 0,20 & 13,93 & 0,13 & 0,20 & 0,17 & 0,10 & 101,17 \\
\hline 128 & 0,14 & 11,12 & 53,79 & 27,22 & 0,34 & 7,06 & 0,07 & 0,21 & 0,31 & 0,11 & 100,37 \\
\hline 129 & 0,17 & 18,62 & 48,57 & 21,90 & 0,22 & 10,89 & 0,06 & 0,26 & 0,22 & 0,09 & 101,00 \\
\hline 130 & 0,09 & 24,35 & 43,58 & 21,68 & 0,27 & 10,55 & 0,09 & 0,28 & 0,33 & 0,11 & 101,33 \\
\hline 131 & 0,05 & 26,64 & 40,16 & 19,83 & 0,19 & 13,43 & 0,13 & 0,26 & 0,24 & 0,09 & 101,02 \\
\hline $132 \mathrm{a}$ & 0,09 & 26,66 & 41,43 & 18,41 & 0,21 & 13,87 & 0,13 & 0,13 & 0,21 & 0,07 & 101,21 \\
\hline 133 & 0,05 & 15,41 & 51,43 & 23,30 & 0,36 & 9,69 & 0,07 & 0,24 & 0,14 & 0,08 & 100,78 \\
\hline 134 & 0,14 & 19,59 & 48,41 & 20,98 & 0,25 & 10,89 & 0,01 & 0,24 & 0,33 & 0,11 & 100,96 \\
\hline 135 & 0,08 & 30,17 & 38,83 & 17,51 & 0,14 & 13,94 & 0,07 & 0,19 & 0,18 & 0,10 & 101,21 \\
\hline 136 & 0,05 & 31,13 & 38,78 & 15,15 & 0,09 & 15,65 & 0,11 & 0,20 & 0,23 & 0,06 & 101,45 \\
\hline 138 & 0,15 & 25,23 & 43,55 & 17,76 & 0,22 & 13,47 & 0,13 & 0,22 & 0,16 & 0,06 & 100,95 \\
\hline 139 & 0,15 & 29,18 & 39,68 & 17,34 & 0,17 & 13,99 & 0,09 & 0,25 & 0,14 & 0,06 & 101,04 \\
\hline 140 & 0,13 & 32,77 & 35,30 & 17,38 & 0,16 & 14,78 & 0,16 & 0,18 & 0,15 & 0,08 & 101,08 \\
\hline 141 & 0,08 & 26,44 & 41,81 & 18,13 & 0,17 & 13,25 & 0,07 & 0,30 & 0,16 & 0,05 & 100,45 \\
\hline 144 & 0,04 & 29,58 & 38,61 & 18,02 & 0,17 & 13,94 & 0,09 & 0,20 & 0,26 & 0,07 & 100,98 \\
\hline 146 & 0,08 & 28,34 & 38,02 & 19,67 & 0,23 & 14,20 & 0,16 & 0,17 & 0,12 & 0,07 & 101,05 \\
\hline 147 & 0,04 & 30,92 & 37,58 & 16,56 & 0,19 & 15,17 & 0,12 & 0,21 & 0,13 & 0,05 & 100,97 \\
\hline 148 & 0,16 & 18,91 & 43,42 & 30,34 & 0,46 & 6,12 & 0,07 & 0,23 & 0,56 & 0,09 & 100,37 \\
\hline 149 & 0,25 & 18,08 & 50,23 & 20,12 & 0,18 & 11,58 & 0,06 & 0,30 & 0,16 & 0,07 & 101,02 \\
\hline 150 & 0,18 & 22,03 & 44,91 & 22,56 & 0,19 & 10,51 & 0,03 & 0,25 & 0,30 & 0,07 & 101,04 \\
\hline 151 & 0,09 & 24,65 & 44,19 & 17,57 & 0,14 & 13,67 & 0,10 & 0,23 & 0,19 & 0,05 & 100,88 \\
\hline 152 & 0,06 & 29,54 & 35,95 & 21,27 & 0,16 & 13,15 & 0,16 & 0,24 & 0,20 & 0,07 & 100,80 \\
\hline 153 & 0,08 & 33,87 & 34,48 & 15,63 & 0,13 & 15,38 & 0,14 & 0,21 & 0,19 & 0,09 & 100,19 \\
\hline 154 & 0,42 & 9,68 & 50,87 & 32,87 & 0,39 & 5,47 & 0,00 & 0,19 & 0,56 & 0,11 & 100,56 \\
\hline 155 & 0,11 & 22,39 & 45,46 & 19,37 & 0,13 & 12,79 & 0,15 & 0,27 & 0,17 & 0,05 & 100,89 \\
\hline 156 & 0,06 & 17,21 & 51,83 & 19,82 & 0,30 & 11,43 & 0,07 & 0,22 & 0,16 & 0,08 & 101,17 \\
\hline 157 & 0,16 & 26,67 & 40,76 & 19,67 & 0,16 & 12,95 & 0,13 & 0,28 & 0,18 & 0,08 & 101,05 \\
\hline
\end{tabular}


Appendix 2 (cont.)

\begin{tabular}{|c|c|c|c|c|c|c|c|c|c|c|c|}
\hline 158 & 0,13 & 21,75 & 46,32 & 21,38 & 0,24 & 10,60 & 0,08 & 0,24 & 0,27 & 0,06 & 101,07 \\
\hline $159 \mathrm{~b}$ & 0,07 & 23,64 & 44,81 & 19,02 & 0,17 & 12,84 & 0,09 & 0,21 & 0,17 & 0,05 & 101,07 \\
\hline 160 & 0,04 & 26,45 & 40,59 & 19,06 & 0,12 & 13,59 & 0,14 & 0,14 & 0,24 & 0,07 & 100,43 \\
\hline 161 & 0,09 & 24,78 & 43,24 & 20,24 & 0,21 & 11,98 & 0,08 & 0,27 & 0,24 & 0,05 & 101,18 \\
\hline 162 & 0,38 & 19,29 & 40,12 & 32,23 & 0,34 & 7,72 & 0,08 & 0,25 & 0,21 & 0,13 & 100,74 \\
\hline 163 & 0,04 & 28,68 & 40,72 & 16,59 & 0,15 & 14,54 & 0,09 & 0,18 & 0,12 & 0,08 & 101,18 \\
\hline 164 & 0,10 & 11,09 & 57,08 & 23,63 & 0,28 & 8,07 & 0,01 & 0,15 & 0,36 & 0,10 & 100,87 \\
\hline \multicolumn{12}{|c|}{ Sample S16 } \\
\hline 166 & 0,12 & 25,09 & 41,13 & 23,36 & 0,29 & 10,10 & 0,06 & 0,21 & 0,63 & 0,12 & 101,09 \\
\hline 168 & 0,17 & 16,16 & 41,50 & 37,87 & 0,79 & 2,32 & 0,04 & 0,08 & 0,72 & 0,13 & 99,77 \\
\hline 169 & 1,26 & 28,45 & 33,09 & 23,56 & 0,17 & 13,57 & 0,16 & 0,23 & 0,15 & 0,04 & 100,67 \\
\hline 170 & 0,07 & 26,32 & 42,61 & 17,65 & 0,13 & 13,90 & 0,13 & 0,24 & 0,18 & 0,06 & 101,30 \\
\hline 171 & 0,33 & 15,38 & 46,62 & 30,52 & 0,43 & 6,67 & 0,04 & 0,19 & 0,53 & 0,11 & 100,82 \\
\hline 172 & 0,19 & 17,19 & 40,89 & 34,43 & 0,59 & 5,91 & 0,09 & 0,34 & 0,76 & 0,06 & 100,45 \\
\hline 173 & 0,23 & 17,55 & 41,78 & 34,21 & 0,48 & 5,51 & 0,05 & 0,19 & 0,59 & 0,08 & 100,67 \\
\hline 174 & 0,12 & 17,55 & 45,18 & 30,68 & 0,31 & 5,86 & 0,06 & 0,27 & 0,71 & 0,10 & 100,84 \\
\hline 175 & 0,25 & 15,73 & 43,53 & 33,39 & 0,38 & 6,75 & 0,10 & 0,21 & 0,28 & 0,06 & 100,69 \\
\hline 176 & 0,14 & 10,85 & 51,77 & 30,05 & 0,45 & 5,78 & 0,06 & 0,22 & 0,70 & 0,12 & 100,14 \\
\hline 177 & 0,11 & 22,52 & 42,59 & 23,75 & 0,20 & 11,46 & 0,10 & 0,29 & 0,15 & 0,07 & 101,23 \\
\hline 178 & 0,18 & 17,14 & 50,27 & 21,63 & 0,26 & 10,70 & 0,03 & 0,22 & 0,14 & 0,09 & 100,66 \\
\hline 180 & 0,30 & 14,46 & 51,77 & 23,94 & 0,23 & 9,13 & 0,06 & 0,32 & 0,22 & 0,09 & 100,50 \\
\hline 181 & 0,63 & 14,89 & 38,61 & 41,02 & 0,35 & 3,48 & 0,07 & 0,23 & 0,43 & 0,07 & 99,78 \\
\hline 182 & 0,36 & 7,16 & 50,33 & 38,16 & 0,39 & 2,39 & 0,07 & 0,14 & 0,51 & 0,13 & 99,65 \\
\hline 183 & 0,09 & 34,30 & 34,85 & 15,53 & 0,14 & 15,16 & 0,13 & 0,21 & 0,19 & 0,06 & 100,66 \\
\hline 184 & 0,12 & 22,13 & 43,01 & 25,40 & 0,21 & 9,07 & 0,05 & 0,30 & 0,63 & 0,11 & 101,03 \\
\hline 185 & 0,15 & 27,66 & 41,52 & 18,02 & 0,14 & 13,67 & 0,04 & 0,26 & 0,17 & 0,06 & 101,69 \\
\hline 186 & 0,05 & 14,44 & 47,64 & 32,24 & 0,32 & 4,42 & 0,05 & 0,28 & 0,74 & 0,14 & 100,32 \\
\hline 187 & 0,66 & 7,40 & 45,09 & 40,25 & 0,39 & 4,69 & 0,11 & 0,17 & 0,46 & 0,11 & 99,33 \\
\hline 188 & 0,07 & 32,36 & 36,68 & 15,70 & 0,14 & 15,00 & 0,13 & 0,16 & 0,34 & 0,08 & 100,65 \\
\hline 189 & 0,52 & 17,59 & 39,34 & 35,80 & 0,37 & 5,86 & 0,16 & 0,30 & 0,42 & 0,11 & 100,46 \\
\hline 190 & 0,14 & 15,57 & 50,31 & 24,58 & 0,29 & 9,39 & 0,10 & 0,28 & 0,24 & 0,09 & 100,98 \\
\hline 191 & 0,19 & 15,26 & 44,37 & 32,92 & 0,37 & 6,24 & 0,04 & 0,18 & 0,61 & 0,10 & 100,28 \\
\hline 192 & 0,33 & 14,53 & 49,22 & 28,77 & 0,46 & 6,16 & 0,03 & 0,24 & 0,72 & 0,15 & 100,60 \\
\hline 193 & 0,24 & 21,88 & 38,75 & 30,17 & 0,29 & 8,00 & 0,07 & 0,24 & 0,44 & 0,10 & 100,18 \\
\hline 194 & 0,35 & 21,47 & 31,78 & 39,09 & 0,39 & 5,65 & 0,11 & 0,33 & 0,80 & 0,08 & 100,04 \\
\hline 195 & 0,47 & 17,52 & 43,13 & 29,12 & 0,27 & 9,29 & 0,08 & 0,28 & 0,07 & 0,06 & 100,28 \\
\hline 196 & 0,35 & 13,17 & 41,62 & 40,03 & 0,55 & 2,85 & 0,13 & 0,17 & 0,65 & 0,09 & 99,61 \\
\hline 197 & 0,25 & 10,62 & 55,67 & 26,18 & 0,40 & 6,82 & 0,01 & 0,15 & 0,55 & 0,11 & 100,75 \\
\hline
\end{tabular}


Appendix 2 (cont.)

\begin{tabular}{lrrrrrrrrrrr}
198 & 0,34 & 26,15 & 31,72 & 29,95 & 0,35 & 7,40 & 0,05 & 0,28 & 0,56 & 0,09 & 96,90 \\
201 & 0,29 & 38,97 & 28,77 & 12,98 & 0,08 & 18,51 & 0,20 & 0,13 & 0,09 & 0,05 & 100,07 \\
202 & 0,57 & 22,23 & 44,95 & 20,97 & 0,25 & 11,58 & 0,08 & 0,16 & 0,20 & 0,11 & 101,10 \\
203 & 0,17 & 18,22 & 47,66 & 24,15 & 0,28 & 10,26 & 0,09 & 0,25 & 0,15 & 0,06 & 101,30 \\
205 & 0,16 & 21,37 & 43,10 & 28,43 & 0,68 & 6,18 & 0,06 & 0,21 & 0,68 & 0,15 & 101,02 \\
206 & 0,15 & 19,63 & 46,16 & 22,80 & 0,18 & 11,17 & 0,11 & 0,26 & 0,14 & 0,05 & 100,66 \\
$208 \mathrm{c}$ & 0,32 & 13,16 & 46,49 & 32,86 & 0,42 & 5,85 & 0,04 & 0,24 & 0,48 & 0,12 & 99,98 \\
209 & 0,22 & 10,60 & 50,95 & 31,53 & 0,36 & 6,24 & 0,01 & 0,24 & 0,32 & 0,13 & 100,60 \\
210 & 0,71 & 20,44 & 40,33 & 31,12 & 0,39 & 7,26 & 0,05 & 0,32 & 0,33 & 0,12 & 101,07 \\
211 & 0,17 & 8,39 & 52,18 & 34,51 & 0,54 & 3,43 & 0,07 & 0,24 & 0,55 & 0,09 & 100,16 \\
213 & 0,22 & 27,91 & 35,59 & 27,34 & 0,29 & 9,17 & 0,05 & 0,26 & 0,36 & 0,08 & 101,27 \\
214 & 0,04 & 31,47 & 36,95 & 17,69 & 0,19 & 14,27 & 0,13 & 0,22 & 0,11 & 0,10 & 101,18 \\
215 & 0,25 & 23,17 & 39,52 & 29,42 & 0,27 & 7,12 & 0,11 & 0,30 & 0,49 & 0,08 & 100,73 \\
216 & 0,06 & 28,10 & 38,85 & 20,82 & 0,24 & 11,50 & 0,14 & 0,24 & 0,24 & 0,10 & 100,29 \\
\hline
\end{tabular}

$\mathrm{a}=\mathrm{Cr}$-spinel with olivine 1, $\mathrm{b}=\mathrm{Cr}$-spinel with olivine 2, $\mathrm{c}=\mathrm{Cr}$-spinel with augite; see Table 3 and text for explanation 